\title{
DOCTRINARIO CONTRA BRUJAS. LOS INDICIOS MATERIALES DE CRIMINALIDAD*
}

\author{
María Jesús Torquemada SÁnchez \\ Departamento de Derecho Romano \\ e Historia del Derecho. Facultad de Derecho \\ Universidad Complutense de Madrid \\ mariajesustorquemada@der.ucm.es
}

\begin{abstract}
RESUMEN
El presente trabajo versa sobre los textos elaborados por la doctrina jurídica entre los siglos XIV y XVII con el fin de ilustrar a los jueces que juzgaban por los crimenes de brujería y supersticiones sobre las sustancias y objetos mágicos que podían aportarse como prueba durante los procesos desarrollados ante los tribunales seculares e inquisitoriales por tales conductas.

Palabras clave: doctrina jurídica, brujería, supersticiones, pruebas materiales, objetos mágicos.
\end{abstract}

\section{ABSTRACT}

The current piece of work is based upon the texts written by judicial doctrine in between the $14^{\text {th }}$ and $17^{\text {th }}$ centuries with the aim to show judges judging based on witchcraft and superstitions on the evidence of substances and magic items bound to provide evidence at secular courts and inquisitorial ones based on the above mentioned behaviour.

Keywords: Judicial Doctrine, Witchcraft, Superstitions, Physical Evidence, Magic Tools.

\section{ZUSAMMENFASSUNG}

Diese Arbeit befasst sich mit den Texten, die von der Rechtslebre zwischen dem 14. und 17. Jabrbundert ausgearbeitet wurden, um die Richter, die über die Verbrechen der Hexerei und des Aberglaubens urteilten, über die magischen Substanzen und Gegenstände aufzuklären, die als Beweismittel während der Prozesse vor den weltlichen und inquisitorischen Gerichten für solche Handlungen herangezogen werden konnten.

Schlüsselwörter: Rechtslehre, Hexerei, Aberglaube, materielle Beweise, magische Gegenstände.

* El presente trabajo se ha llevado a cabo en el marco del proyecto de investigación concedido por la Fundación Séneca titulado La responsabilidad jurídica en la Europa moderna y contemporánea (siglos XV-XX), cuya referencia es 20787/PI/18. 
SUMARIO: I. LOS ANTECEDENTES. ALGUNAS PINCELADAS PREVIAS A LA EDAD MODERNA.-II. LOS INDICIOS MATERIALES DE CRIMINALIDAD SEGÚN VARIOS TRATADISTAS.-III. A MODO DE RECAPITULACIÓN.

«Venían a ella muchos hombres y mujeres, y a unos demandaba el pan do mordían; a otros, de su ropa; a otros, de sus cabellos; a otros, pintaba en la palma letras con azafrán; a otros, con bermellón; a otros daba unos corazones de cera llenos de agujas quebradas, y otras cosas en barro y en plomo hechas, muy espantables al ver. Pintaba figuras, decía palabras en tierra. ¿Quién te podrá decir lo que esta vieja hacía?».

Fernando DE Rojas, La Celestina, Acto I.

\section{LOS ANTECEDENTES. ALGUNAS PINCELADAS PREVIAS A LA EDAD MODERNA}

A lo largo de los siglos, muchos seres humanos no se han conformado con la realidad circundante, intentando por medios diversos trascender lo tangible y cotidiano en busca de condiciones distintas que pudieran mejorar su existencia. Gracias a tales inquietudes se han producido los mayores avances de la humanidad y se han llevado a cabo los grandes inventos y descubrimientos que nos alejan de los tiempos en que la naturaleza tenía siempre la última palabra en el devenir de los individuos y las sociedades.

En algunas ocasiones, esa necesidad de romper las barreras de lo que en cada periodo era científicamente explicable ha producido más de un problema en el seno de ciertas comunidades pretéritas, que atribuían a fuerzas desconocidas y remotas los acontecimientos que no eran capaces de comprender con las herramientas que les proporcionaba la razón. Dentro de ese escenario la magia se convierte en el mejor instrumento para lograr lo que no se puede conseguir de forma natural o por medio de la ciencia. Pero a la hora de traspasar esos límites, no quedaba más remedio que aferrarse a los objetos y elementos cotidianos que se hallaban al alcance de quienes cometían la osadía de adentrarse en el mundo de la magia, a fin de que estos sirvieran como hilo conductor y canalizador de energías ocultas. La materialidad de los mismos los convertía en indicios que las autoridades podían detectar para utilizarlos a modo de prueba a la hora de reprimir esos crímenes relacionados con la magia. 
Antes del imperio de la razón las personas se servían del trinomio naturaleza, magia y religión para explicar lo incomprensible. La divinidad, dueña de todo el universo, se manifestaba a través de los fenómenos naturales por medio de la magia que llevaban a cabo ciertos individuos especialmente dotados al efecto: «magos», «sacerdotes», hechiceros», «chamanes», etc., actuaban siempre dentro de la ortodoxia señalada por quienes gobernaban esos grupos humanos, comúnmente de ámbito reducido, en los que tales personajes desplegaban sus asombrosos y esotéricos poderes.

La creencia generalizada en que algunos rituales y sustancias canalizaban la potestad de los dioses en pro de los seres humanos o en contra de sus enemigos era moneda común dentro de aquellas comunidades pretéritas. Así evolucionó la humanidad durante muchos siglos tanto en Europa como en cualquier otro lugar del mundo. Así sigue siendo en el seno de algunas sociedades primitivas contemporáneas.

Magia y religión estaban íntimamente relacionadas, pues existía la creencia de que solo se podían obrar prodigios a través de las prácticas religiosas y con la intercesión de la divinidad. El concepto de milagro fue y es todavía sinónimo de «magia buena» y deseable entre los creyentes.

Aunque ya desde la Antigüedad se observa una cierta prevención por parte de las autoridades laicas y religiosas hacia la «magia negra» o maleficio, vulgo «brujería» ${ }^{1}$, es a partir de la Edad Media cuando los poderes civiles y religiosos comienzan en Europa una verdadera cruzada para hacer valer sus reglas y directrices en lo tocante a aquello que debe ser considerado admisible o punible a la hora de utilizar rituales, sustancias u objetos mágicos.

La virtualidad de la magia tanto para favorecer como para dañar a los individuos, animales y cosas era comúnmente admitida por las autoridades y los súbditos hasta que se planteó oficialmente la dicotomía ortodoxiaheterodoxia en el marco de la Europa medieval. En ese punto entran ínti-

${ }^{1}$ Ya en la Biblia encontramos durísimas sanciones contra las personas que practicaran la magia negra: Éxodo, 22: 18: «No dejarás con vida a la hechicera», y Levítico, 20: 27: «Y el hombre o la mujer que evocare espíritus de muertos o se entregare a la adivinación, ha de morir; serán apedreados; su sangre será sobre ellos». En la Antigua Roma, la Ley de las XII Tablas, tabla VII, «De los Crímenes», castiga los ritos encaminados a dañar las cosechas ajenas: Ley III: «Cualquiera que, mediante encantos y artes mágicas evite el crecimiento de las cosechas ajenas, será sacrificado a Ceres». Más tarde, durante el Bajo Imperio, seguirían estas actividades siendo castigadas con la pena de muerte precedida de horribles tormentos: C. TH. 9, 16, 6. Seguiría en la misma línea la legislación justinianea del Corpus Iuris Civilis: Codex Iustiniani, 9, 18. 
mamente en contacto el elemento religioso y los poderes laicos. La Iglesia y el Imperio, aun existiendo un mutuo y tradicional recelo entre ambos, se aliaron para mantener el cosmos que favorecía sus posiciones de privilegio frente al común de la población europea.

Si bien, como se ha mencionado, ciertas prácticas mágicas habían estado reprimidas desde antiguo en el seno de la civilización judeocristiana, no revestían estas mayor importancia a los ojos de los gobernantes mientras perduró el fraccionamiento de los poderes eclesiásticos y civiles a lo largo de la Alta Edad Media, con una diversidad de reinos y señoríos surgidos tras las invasiones bárbaras. A ello se le añadiría la proliferación de las iglesias nacionales.

A medida que comienzan a vislumbrarse los cambios que darían paso a esa etapa que conocemos como la Baja Edad Media, caracterizada, sobre todo, por la fiebre unificadora de credos y poderes públicos en el seno de la cristiandad, cualquier particularidad de índole política o religiosa caería bajo sospecha, siendo desde ese momento una prioridad para la Res Publica cristiana revertir cualquier disidencia que amenazara la ansiada unidad: Unum Imperium, Unum Ius².

El proceso a lo largo del cual los rituales mágicos pasaron de ser promovidos por las propias autoridades públicas a ser perseguidos y reprimidos por estas duró, pues, muchos siglos. La prohibición de tales creencias y, sobre todo, la manifestación de las mismas ad externum cuando no se encuadraban perfectamente en el marco de la ortodoxia político-religiosa, trajo consigo la represión de la herejía en tanto en cuanto suponía la divergencia con respecto al camino marcado por los poderes fácticos. Esa mentalidad fue el motivo por el cual tuvieron lugar las grandes cazas de brujas en Europa.

El surgimiento de las primeras herejías encuadradas en los albores de la Baja Edad Media puso en guardia a las autoridades acerca de la amenaza que se cernía sobre esa pretendida unificación y, por supuesto, sobre la posición hegemónica que ostentaban el emperador y el papa desde el siglo XI. La dualidad Dios-demonio toma forma definitiva para identificar la voluntad divina con la recta doctrina de la Iglesia, abanderada por el pontífice y no por los concilios nacionales después del Dictatus Papae de Gregorio VII. Ello supone que en el ámbito religioso había triunfado el centralismo de poder frente a la previa hegemonía de los concilios que se repartían por la cristiandad. Lo mismo había ocurrido en lo tocante a

${ }^{2}$ M. Bellomo, La Europa del Derecho común. Roma, Il Cigno Galileo Galilei, 1996. 
los poderes temporales, rendidos ante la supremacía del emperador del Sacro Imperio.

Todo ello traería consigo la aparición de algunos escritos elaborados por ciertos expertos teólogos con la finalidad de separar las creencias admisibles de las que no lo eran a su juicio. Eso tuvo enorme trascendencia cuando las autoridades civiles y religiosas se percataron de que los súbditos, ante las contingencias adversas de su vida cotidiana o también a la vista de las grandes catástrofes ocasionadas por las guerras, la sequía u otras calamidades que se veían obligados a sufrir en no pocos casos a causa de los propios errores cometidos por quienes les gobernaban, volvían sus ojos hacia otras formas de poder sobrenatural diferentes de las que regían el universo cristiano desde los parámetros de la ortodoxia implantada por los poderes fácticos. Esa tendencia, a los ojos de las autoridades político-religiosas, debía ser reprimida para evitar que se expandiera, ganando así terreno a costa del orden que interesaba a quienes en esos momentos ostentaban el poder. A partir de entonces se identificó el retorno a las viejas religiones precristianas o cualquier otro tipo de disidencia con el culto al demonio. Tales creencias, en muchos casos anteriores incluso a la etapa del Imperio romano, habían permanecido en el imaginario colectivo de forma soterrada. Se habían estado practicando a lo largo de los siglos ciertas ceremonias consideradas paganas que convivían con las cristianas sin aparente contradicción o choque entre ellas.

A partir de los albores de la Baja Edad Media, las fuerzas del mal fueron identificadas con cualquier movimiento heterodoxo o cismático cuyo mejor ejemplo es la herejía de los cátaros, surgida en el siglo x y ampliamente implantada en el Mediodía francés ya en el siglo XII ${ }^{3}$. No tardaron esos herejes en ser acusados de practicar ritos demoniacos con el fin de justificar la despiadada persecución a la cual fueron sometidos por parte de las autoridades seculares y eclesiásticas.

Los obispos, encargados por el pontífice de perseguirlos y castigarlos, acusaban a los cátaros («puros», según la palabra de origen griego que los identificaba) de demonolatría entre otras desviaciones.

Ese fue el germen de las cazas de brujas que asolaron buena parte de Europa durante la Edad Moderna, dado que la típica imagen de la bruja y el diablo van de la mano entre los siglos XV y XvIII.

El fenómeno de la brujería se persiguió desde diferentes perspectivas y con distinta intensidad en los diversos territorios europeos. En los países

3 S. O’SHEA, Los cátaros: la herejía perfecta, Barcelona, Zeta Bolsillo, 2010 (1. a ed., 2002). 
del centro y norte del continente, así como en las islas británicas, se instaló con firmeza la creencia popular de que ciertas personas, generalmente pertenecientes al género femenino, eran capaces de ejercer el maleficium sobre sus semejantes con la intercesión del demonio, idea que no fue fomentada por la Iglesia ni por los tribunales inquisitoriales, sino todo lo contrario. Esas instituciones funcionaron como muro de contención e incluso como represoras de tales teorías.

Tanto la Iglesia como las diferentes inquisiciones europeas eran organizaciones centrípetas y unificadoras de las normas que debían regir sus actuaciones, propugnando la mencionada implantación de un derecho común para toda la cristiandad. Ese orden jurídico haría fortuna en los foros dependientes del papa, del emperador del Sacro Imperio y de los reyes europeos que pretendían concentrar el poder en su persona a despecho de los señoríos diversos y dispersos generados a partir de los parámetros propios del régimen feudal subsiguiente al derrumbamiento del Imperio romano de Occidente. Por ello, dichos poderes unificadores chocaban frontalmente con los gobernantes que ejercían su dominio sobre territorios de honda raigambre feudal, fragmentados y atomizados en sus estructuras políticas y jurídicas.

El establecimiento del llamado Derecho común libró a los territorios donde se impuso frente a los sistemas jurídicos preexistentes de las temibles y sanguinarias cazas de brujas que padecieron los señoríos de estructura feudal durante buena parte de la Edad Moderna, ello gracias a la implementación de una administración de justicia que se nutría de jueces y abogados expertos, debidamente formados en unas normas y técnicas jurídicas que no contemplaban como elementos dignos de ser tenidos en cuenta todas las supersticiones rampantes entre las masas campesinas ${ }^{4}$.

Ese Derecho romano-canónico no llegó, desafortunadamente, a los reductos en donde los señores territoriales ejercían su autoridad con exclusión de otros órganos de poder.

Así pues, tales supersticiones populares unidas a los miedos generalizados en un panorama donde unos magnates territoriales, despreciando el Derecho común, administraban justicia por medio de normas consuetudinarias y acientíficas, dieron como resultado linchamientos masivos a modo de justificación y lenitivo para cualquier desgracia colectiva sobrevenida sin razón aparente, si bien en muchas ocasiones esos males no eran sino

\footnotetext{
${ }^{4}$ A. PÉrez Martín, El Derecho procesal del «Ius Commune», Murcia, Universidad de Murcia, 1999.
} 
la consecuencia de la propia ineptitud de los propios gobernantes, que se prestaban a tales sacrificios humanos con el solo deseo de apaciguar a las masas de súbditos enfebrecidos por la convicción de que las presuntas brujas podían dañar sus personas y bienes.

Solamente en las regiones y países donde consiguió imponerse el mencionado Derecho común, mezcla de normas básicamente procedentes de las tradiciones romana y canónica, la administración de justicia se sustentaría sobre sólidas bases jurisdiccionales en las cuales los técnicos en Derecho se ubicaban en tribunales que actuarían conforme a una rígida disciplina técnico-jurídica. No sería ese el caldo de cultivo idóneo para que germinaran unas cazas de brujas basadas fundamentalmente en las supersticiones generadas por los campesinos y secundadas por los señores territoriales que imponían su orden sobre la base de un poder omnímodo ejercido en el ámbito de sus pequeños reductos y atendiendo más a determinadas normas consuetudinarias que al tecnicismo de las leyes inspiradas en el Derecho romano, ingrediente fundamental del nuevo Derecho común bajomedieval.

Podemos encontrar unas ciertas condiciones de benignidad relativa a la hora de afrontar el fenómeno de la brujería solo allí donde los poderes político y religioso se hallaban fuertemente centralizados a causa, sobre todo, de la incredulidad manifestada por quienes estaban destinados a juzgarlo y reprimirlo, principalmente las diferentes inquisiciones, incluyendo la española.

Centrándonos en el caso de España, se observa en este sentido un fuerte contraste entre el tratamiento que se les dio a los brotes de brujería dentro de los territorios de la mitad norte de la península antes de la implantación de la Inquisición española en 1478. Con anterioridad a ese año, la herejía de los cátaros había atravesado los Pirineos y se había extendido a ciertas regiones pertenecientes a la corona de Aragón 5 . Según las autoridades, esa doctrina de alguna manera llevaba aparejada la creencia en los poderes del diablo para expandir su semilla. Ello condujo a una psicosis colectiva relacionada con la brujería. En las citadas regiones y en otros territorios del norte peninsular se produjeron distintas acusaciones contra presuntos brujos que culminaron en despiadadas persecuciones llevadas a

5 D. BARRERA, La Cruzada albigense y el imperio aragonés: la verdadera historia de los cátaros, Madrid, Nowtilus, 2007. Alguna obra, como la de Johannes Tinctor titulada Invectives contre la secte de vauderie (1460), se ha constituido como un verdadero tratado relativo a la persecución de los valdenses bastante tiempo antes de la aparición del Malleus Maleficarum, aparecido en 1487. 
cabo por los poderes políticos locales y fragmentarios, hasta que el Santo Oficio español se hizo cargo de esos supuestos delitos desde los órganos centrales de la monarquía española, poniéndose así freno a las cacerías de brujos que empezaron entre los siglos XIV y XV. Ello fue posible desde la implantación de un régimen jurídico que implementaba el proceso inquisitivo frente al acusatorio tradicional, menos racional y técnico que el primero, de manera que se evitó la importación de actuaciones similares a las que tuvieron lugar en el centro y norte de Europa.

La figura señera del inquisidor Salazar y Frías, pionero abanderado de la incredulidad respecto a los pretendidos poderes de las brujas en la Navarra del siglo XVII, propició una profunda reflexión por parte de quienes deberían establecer las normas de actuación frente a ese tipo de delitos en la España peninsular y en la de allende los mares, salvándose de ese modo las vidas de muchos que fueron acusados de prácticas supersticiosas entre los siglos XVII y XIX, sin por ello renunciar el Santo Oficio español a la represión de las manifestaciones heterodoxas relacionadas con el mundo de la magia ${ }^{6}$.

A medida que la llamada civilización occidental empezó a construir un cosmos prioritariamente científico, cosa que sucede desde que la filosofía de la Ilustración eclosionó para culminar en el marco de la Revolución francesa, la razón como máxima expresión de la naturaleza humana y de lo que debería constituir una adecuada construcción jurídica prevaleció netamente sobre los otros dos componentes del trinomio que explicaba el mundo circundante con anterioridad al siglo XVIII. La religión pasó a un segundo plano y con ella las prácticas mágicas cayeron en el más profundo descrédito, siendo ignoradas desde ese momento por el universo jurídico excepto cuando entrañasen graves riesgos para la integridad de las personas o sus bienes. Quedarían como actividades o creencias pecaminosas cuyos practicantes deberían rendir cuentas en los confesonarios.

Pero antes de que las leyes represoras de las supersticiones suprimieran estas de los códigos penales occidentales, los tribunales y juzgadores encargados de la persecución y castigo de las actividades relacionadas con la magia heterodoxa debían buscar apoyos doctrinales y jurídicos a la hora de determinar la culpabilidad o la inocencia de los acusados. En realidad, la legislación relativa a todas esas cuestiones puede calificarse de escasa en España y fuera de ella.

${ }^{6}$ G. Henningsen, El abogado de las brujas. Brujería vasca e Inquisición española, Madrid, Alianza Editorial, 1983. 
Desde que la Inquisición española fue expresamente encargada de incluir tales prácticas en su ámbito de actuación, la legislación previa relativa a esos delitos respondía más al sistema acusatorio de administración de justicia que al inquisitivo, propio del Santo Oficio. Se trataba generalmente de normas insertadas en los textos jurídicos locales con raigambre consuetudinaria por las cuales los acusados obtenían su veredicto a través del sistema de ordalías. La implantación del Santo Oficio tras la bula de Sixto IV en 1478 supuso un cambio fundamental en el tratamiento jurídico del delito de brujería, pues es sabido que el proceso inquisitorial excluye los juicios de Dios, estableciendo la obligación que tienen los jueces de inquirir y averiguar acerca de las circunstancias del presunto crimen, todo ello por medio de un sistema probatorio mucho más próximo al actual. De ese modo, la Inquisición española partía de un escaso contingente legal a la hora de proceder contra esos y otros delitos. Esa carencia se paliaba a través de varios sistemas tendentes a rellenar las lagunas legales. Por una parte, se solicitaba de los máximos órganos inquisitoriales la generación de soluciones dispositivas que podían dirigirse a todos los tribunales de distrito y que pasarían ulteriormente a insertarse dentro del acervo jurídico inquisitorial en forma de Instrucciones, Cartas Acordadas, etc. Por otro lado, el hecho de elegirse a los inquisidores entre individuos que se presentaran como expertos teólogos, generalmente versados en el Derecho común, garantizaba en cierta medida que sus soluciones jurisdiccionales se apoyaran en las obras de otros teólogos y juristas que habían publicado tratados donde se analizaba técnicamente el delito de herejía en todas sus variantes, incluida la creencia en la magia supersticiosa.

El delito de brujería y supersticiones no era, pues, una excepción a ese modo de proceder, de manera que ante la evidente escasez de leyes y otras normas que indicaran a los inquisidores la forma de actuar frente a los presuntos brujos, las obras doctrinales relativas a estos delitos revistieron una enorme importancia a lo largo de todos los siglos durante los cuales aquellos tribunales inquisitoriales hubieron de juzgar la magia heterodoxa y supersticiosa, erigiéndose en el necesario apoyo supletorio de las leyes inexistentes o confusas.

La actividad judicial en lo que respecta a estos delitos relacionados con la magia se llevaba a cabo, pues, a tres bandas. Por una parte, los jueces inquisitoriales tenían en cuenta la propia normativa del Santo Oficio, escasa como se ha apuntado antes pero que sentaba las bases y directrices fundamentales para que los tribunales pudieran sustanciar y sentenciar los correspondientes procesos. Por otro lado, a falta de esas normas, 
los inquisidores siempre podían recurrir a la doctrina de los tratadistas, de cuyas páginas bebieron en su día los órganos supremos de la Inquisición a la hora de generar las primeras y ulteriores Instrucciones y Cartas Acordadas del Santo Oficio.

Pero, además, en el caso de los delitos que se analizan en este estudio, no se pueden olvidar las propias prácticas cotidianas llevadas a cabo por quienes eran acusados de tales ilícitos. Por mucho que la Inquisición o los tratados relativos al Santo Oficio pretendieran abarcar el elenco de las manifestaciones y objetos que debían considerarse sospechosos de herejía en lo tocante a la brujería y las supersticiones, la realidad cotidiana siempre iba por delante de todas las formulaciones legales o doctrinales, de manera que llegó un momento en que se hizo necesaria la aplicación analógica de las normas y la interpretación casuística de los escritos de los tratadistas, fuentes teóricamente proscritas del ámbito jurídico castellano en el cual se encuadraba la Inquisición española a determinados efectos desde el Ordenamiento de Alcalá de 1348. En este punto es donde entra de lleno el problema de la prueba. Al haber abandonado el Santo Oficio el sistema probatorio de las ordalías en favor de las pruebas testificales y materiales de los delitos que juzgaba, se imponía elaborar algún elenco de objetos y sustancias que fuera indicativo de la comisión de esos crímenes de brujería y supersticiones. La prueba testifical no siempre era fácil de conseguir en estos casos, dado que esos delitos se encuadraban dentro de los llamados ocultos, puesto que no se llevaban a cabo de manera pública, sino con sigilo y en secreto. La principal prueba dentro del proceso inquisitorial, la confesión del reo, solía resultar difícil de obtener, pues la tortura se reservaba para contados casos en que otros indicios del delito resultaran confusos. Por eso las pruebas materiales revestían especial importancia en la instrucción de los procesos por brujería y supersticiones.

La doctrina penalista y las obras de los teólogos fueron ampliando a lo largo de varios siglos la lista de las ceremonias, objetos y sustancias sospechosos de la herejía de los brujos en una vana carrera para ponerse al día respecto a la praxis cotidiana desarrollada por esos delincuentes del ocultismo. Todo se consideraba válido en un desesperado intento de que los tribunales inquisitoriales y también los civiles, allá donde los delitos relacionados con la magia no fueran juzgados por la Inquisición, tuvieran un apoyo teórico en el cual fundamentar su legislación y sus decisiones, apartándolos así de la pura arbitrariedad existente en los territorios donde esas actividades se castigaban de acuerdo con el sistema acusatorio de raigambre puramente altomedieval. Pero era un esfuerzo baldío, pues la magia 
supersticiosa y heterodoxa siempre iba un paso por delante de quienes teorizaban sobre ella.

Ese puede ser uno de los motivos por los cuales la mayoría de las obras doctrinales que se ocuparon del delito de herejía, y, más concretamente, de la brujería y las supersticiones, fueron redactadas preferentemente entre los siglos XV y XVII, si bien la Inquisición española continuó su actividad y, consiguientemente, la represión de la magia supersticiosa hasta el primer tercio del siglo XIX.

A lo largo de estas páginas, nos proponemos resaltar de manera especial la interacción entre esos delincuentes y los teóricos de la herejía a través de sus intermediarios, los tribunales inquisitoriales, aun estando los primeros siempre tan alejados de la realidad fáctica sobre la que redactaban esas obras doctrinales.

Abordaremos ese fenómeno siempre desde el punto de vista de los objetos reputados mágicos en la etapa que media entre los siglos XIV y XVIII. Se trataba de un fenómeno de feedback o retroalimentación por medio del cual los delincuentes suministraban a la doctrina los datos relativos a las ceremonias y artículos que utilizaban en sus prácticas mágicas por medio de las pruebas que constaban contra ellos en los procesos judiciales. A su vez, los propios delincuentes podían tener acceso a través de esas obras a los repertorios de objetos considerados propios de la magia demoniaca por parte de la ortodoxia.

Son, en efecto, muy numerosos los tratados sobre embrujos y sortilegios que inundaron Europa durante el periodo que se extienden entre la etapa medieval y los albores del siglo XIX. Tales obras se generaban desde un doble frente: por un lado, el de los que expandían ese tipo de prácticas y creencias por creer en su eficacia, y, por otro, el de los que las perseguían con el fin de erradicarlas.

Ríos de tinta se vertieron acerca de las diversas cuestiones relacionadas con la magia supersticiosa durante el periodo que media entre los siglos XIV y XVII. Los escritores que dedicaron muchas páginas de sus obras a las actividades que se consideraban delictivas a lo largo de todos esos años se encuadraban en diferentes ámbitos del saber. Por una parte, estaban los teólogos preocupados por la expansión de una herejía que no había tenido mayor eco durante los periodos previos a la Baja Edad Media, pero que había prendido como la pólvora a partir del comienzo de dicha etapa. Era bastante frecuente que esos teólogos tuvieran, además, una sólida formación jurídica desde que se creara la amalgama denominada Derecho romano-canónico, pues no en vano una buena parte de ese también 
denominado Derecho común se sustentaba sobre las normas canónicas generadas por la Iglesia desde antiguo y sistematizadas en las obras recopiladoras llevadas a cabo por Graciano, Raimundo de Peñafort, etcétera.

Podría considerarse que ese carácter bifronte se extendía también a ciertos juristas formados en las universidades donde se enseñaba ese nuevo Derecho, quienes, sin tratarse de teólogos, conocían y dominaban los conceptos que servían de fundamento a la ortodoxia religiosa contemporánea gracias a las enseñanzas de los canonistas que habían impartido sus enseñanzas en las universidades donde tuvo lugar la generación de esa nueva construcción jurídica bajomedieval.

Además, dentro de la legión de tratadistas que dedicaron sus páginas a dilucidar estas cuestiones relacionadas con las prácticas del ocultismo fuera de la ortodoxia católica, encontramos a quienes redactaron monografías sobre las mismas y a otros que las trataron al hilo de obras generales que desglosaban los pormenores relativos a los diferentes delitos ${ }^{7}$.

A este respecto hay que señalar una diferencia notable entre ambos grupos. Los monografistas suelen plasmar en sus obras una creencia exacerbada en las prácticas que pretenden combatir dentro de sus escritos, mientras que los generalistas del Derecho penal normalmente plantean una visión más racional y menos fanática a la hora de insertar esos crímenes en sus tratados.

$\mathrm{Al}$ referirse este trabajo fundamentalmente al tratamiento doctrinal que recibieron las pruebas materiales de los delitos de brujería y supersticiones, conviene advertir que se debería añadir como grupo aparte, aunque vinculado con los anteriores, el compuesto por los escritores que se especializaron en la forma de perseguir y castigar esos crímenes dentro del foro inquisitorial, por tratarse de delitos mixti fori, es decir, susceptibles de ser juzgados tanto por los jueces laicos como por los tribunales del Santo Oficio, siendo competentes estos últimos cuando esas actividades o creencias revistieran tintes heréticos, cosa que sucedía casi siempre.

No se debe obviar tampoco el hecho trascendental del muy diferente tratamiento jurídico que recibieron esos delitos dependiendo del ámbito geográfico en que se perpetraran. Las grandes cazas de brujas que tuvieron lugar en el centro y el norte de Europa no se produjeron en los países

7 C. Bolaños Mejías, «La literatura jurídica como fuente del Derecho inquisitorial», Revista de la Inquisición, núm. 9 (2000), pp. 191-220. La autora presenta en estas páginas un repertorio de literatura jurídica relativa al funcionamiento del Santo Oficio español, separando las obras de autores especializados en la Inquisición de las escritas por penalistas y civilistas que le dedicaron cierta atención a los temas inquisitoriales. 
donde la Inquisición se ocupó de juzgar y castigar estos delitos. En aquellas regiones húmedas algunas obras como el archiconocido Malleus Maleficarum (Martillo de Brujas), de Kramer y Sprenger ${ }^{8}$, generalmente fechado en 1487, o la obra de Jean Bodin ${ }^{9}$, De la Demonomanie des Sorciers, publicada en 1580, sirvieron como libros de cabecera a jueces ignorantes de toda garantía procesal propia del sistema inquisitivo preconizado por el Derecho común, abordando los brotes de brujería sobre la base de normas consuetudinarias que conducían frecuentemente a linchamientos de las presuntas brujas con el fin de aplacar la histeria generada en el seno de muchas poblaciones campesinas. Sus autores no escatimaron crueldad y fanatismo a la hora de censurar a quienes protagonizaban la versión más demoniaca de todas las herejías.

Por el contrario, el alto grado de formación jurídica desplegado por quienes componían los tribunales inquisitoriales hizo que los territorios comprendidos en el ámbito de actuación de la Inquisición quedaran felizmente excluidos de la caza despiadada de brujos y sortílegos.

Los jueces del Santo Oficio español, generalmente nombrados entre expertos teólogos, recelaban de las obras redactadas sobre esas materias al margen de la tradición jurídica romano-canónica, muy poco amiga de las creencias mágicas y supersticiosas que campan a sus anchas en obras como el Malleus Maleficarum, por poner un ejemplo.

Los inquisidores españoles, haciendo gala de un racionalismo pre$\mathrm{COz}$ en lo que respecta a los temas esotéricos y supersticiosos, nunca creyeron verdaderamente en los presuntos poderes de los brujos, de manera que se enfrentaban a los procesos por brujería desde una óptica totalmente distinta a la de otros juzgadores europeos. En los territorios hispánicos el Santo Oficio no se preocupaba específicamente del maleficium, puesto que no creía que ser humano alguno pudiera generarlo por medios mágicos. La consigna para los inquisidores en lo tocante a estos delitos consistía en la averiguación meticulosa a lo largo de un procedimiento extraordinariamente reglado acerca de si los reos adoraban o no al diablo, pues en ello radicaba la herejía que esos jueces habían recibido el encargo de extirpar. El Maleficium, sin embargo, se daba por hecho en los territorios

${ }^{8}$ H. Kramer y J. Sprenger, Malleus Maleficarum, Lyon, 1669, disponible en bttps:// books.google.es/books/ucm?vid=UCM5319051264Eprintsec=frontcoverEredir_esc $=y \# v=$ onepageEqEf=false (consultado el 8 de septiembre de 2020).

9 J. Bodin, De la Demonologie des Sorciers, París, 1587, disponible en https://babel.hathitrust.org $/ \mathrm{cgi} / \mathrm{pt}$ ? id=dul1.ark:/13960/t6155j30bEview=1up\&seq=5 (consultado el 12 de octubre de 2020). 
que prescindían del proceso inquisitivo para aplicar el sistema acusatorio de las ordalías a la hora de determinar si alguien debía ser o no considerado como reo del delito de brujería. Indicios de criminalidad tales como las denominadas marcas del diablo, rasgos físicos que se presuponían presentes en el cuerpo de los brujos y que podían abarcar un amplio abanico que comprendía la existencia de lunares, mechones blancos en el cabello, antojos, verrugas, heterocromía en el iris de ambos ojos, etc., se convirtieron en elementos acusatorios y probatorios durante un proceso judicial impregnado de discrecionalidad y falta de garantías para los reos. En este régimen judicial la propia ordalía probatoria se convertía muchas veces en un castigo letal para los acusados ${ }^{10}$.

El Malleus Maleficarum fue temprana y felizmente prohibido por la Inquisición española, organización que preferiría, a la hora de juzgar estos crímenes, empaparse de la doctrina que habían vertido en sus escritos algunos teóricos españoles o italianos.

En ocasiones se trataba de especialistas en materias inquisitoriales. Tal era el caso del aragonés Eymeric ${ }^{11}$ en el siglo xIV o del italiano Carena, que redactó su Tractatus antes de mediados del siglo XVII ${ }^{12}$. Además, en no pocas obras genéricas relativas al Derecho penal se insertaba el crimen de herejía como uno más de los perseguibles por parte de las autoridades civiles y religiosas ${ }^{13}$.

${ }^{10}$ Pensemos, por ejemplo, en la ordalía del agua consistente en la inmersión de las brujas con la finalidad de observar si flotaban, lo cual demostraría su culpabilidad debido a la creencia muy extendida de que estaban hechas de una sustancia muy liviana que les impedía hundirse. Si, por el contrario, el reo se hundía pereciendo por ahogamiento quedaría demostrada su inocencia. La misma crueldad se ponía de manifiesto en la ordalía del hierro candente, profusamente utilizada durante la etapa medieval en todos los territorios europeos, incluidos los españoles, por imperativo de numerosos estatutos locales. Ello quedó plasmado en los fueros locales de la península ibérica. Los sistemas inquisitoriales prohibieron ese tipo de procedimientos probatorios a la hora de detectar a los brujos, mientras que allí donde no se estableció una administración de justicia centralizada y basada en el proceso inquisitivo, se siguieron practicando esas ordalías a lo largo de la Edad Moderna.

${ }^{11}$ Nicolau Eymeric nació en Gerona en 1320, ingresando con catorce años en la orden de los dominicos. Luego se formó en el Derecho común durante sus estudios en Toulouse y París. Fue nombrado inquisidor general para Aragón en 1357, más de un siglo antes de que se instaurase la Inquisición española. Su obra Directorium Inquisitorum (circa 1376) tuvo gran eco durante la Baja Edad Media y a lo largo de la Edad Moderna, siendo de mucha utilidad para los inquisidores españoles. Sobre este autor vid., por ejemplo, J. A. ForTEA (ed.), Manual de Inquisidores. Directorium Inquisitorum de Fray Nicolás Eymeric, Madrid, La Esfera de los Libros, 2006.

${ }^{12}$ C. Carena, Tractatus de Officio Sanctissimae Inquisitionis, Cremona, 1641.

${ }_{13}$ Un buen ejemplo lo tenemos en Francisco DE LA PradilLa, autor de la obra titulada Summa de las leyes penales, Madrid, 1639. Este dedica la parte 1. ${ }^{\text {, }}$, cap. XIII, al delito de 
En la obra de Eymeric, los asuntos relacionados con el delito de brujería adquieren especial relevancia debido a que antes de redactarla su autor se dedicó de manera particular a la persecución de este crimen, conociendo de primera mano las obras destinadas a ilustrar a los brujos y sortílegos con instrucciones para llevar a cabo sus ceremonias mágicas, al haber incautado no poca cantidad de esos escritos durante la etapa en que ejerciera como inquisidor del Santo Oficio medieval.

Algunas de esas obras se redactaban a modo de manuales de orientación destinados a prevenir contra tales actividades y otras aludían a la forma de clasificarlas y castigarlas, sin olvidar las que indicaban la forma de realizarlas con éxito ${ }^{14}$.

Sea como fuere, un rasgo común a la mayoría de esas obras se centra en que no solían aspirar a ser útiles para la represión de esos delitos en un territorio concreto. Generalmente tenían vocación de universalidad y sus autores pretendían que se pudieran utilizar en cualquier lugar donde se practicaran tales modalidades heréticas.

La principal tarea de los inquisidores y de la doctrina jurídica consistía, pues, en interactuar con el fin de proporcionarse mutuamente las claves para hacerles frente a esos delincuentes. La praxis de los tribunales se mezclaba con las obras de los estudiosos del Derecho, que salían al paso de tales prácticas heterodoxas con el fin de teorizar acerca de qué hacer al respecto y de cómo catalogar los hechos cometidos por semejantes herejes.

Herejía, disponible en https://babel.hathitrust.org/cgi/pt?id=ucm.5319430647\&view=1upEs $e q=8$ (consultado el 22 de octubre de 2020).

A caballo entre los penalistas generalistas y los especialistas en el delito de herejía están otros autores como Alfonso DE CASTRO, cuya primera obra titulada Adversus omnes haereses, París, 1534, hace un repaso de las diversas herejías que han surgido en el seno de la Iglesia desde sus orígenes. También es el autor de la obra titulada De iusta baereticorum punitione, Salamanca, 1547. Se puede consultar la primera de ellas en https://babel.hathitrust. $\mathrm{org} / \mathrm{cgi} / \mathrm{pt}$ ? id=ucm.5319430647Eview=1 up\&seq=8, y la segunda de las obras mencionadas puede consultarse en https://babel.hathitrust.org/cgi/pt?id=ucm.5325043668Eview=1upEs $e q=5$ (consultadas ambas el 8 de noviembre de 2020).

${ }_{14}$ El jesuita español Martín DEL Río es autor de una obra titulada Disquisitionum Magicarum Libri sex, Maguncia, 1623. Se trata de una obra muy extensa y universal que fue citada frecuentemente por quienes escribían tratados acerca de estas cuestiones, pudiendo hallarse múltiples alusiones a la misma, por ejemplo, en la importante obra de César Carena que examinaremos detenidamente más adelante. Desde su aparición fue considerada referencia obligada por su amplitud y meticulosidad. Sin embargo, para el estudio concreto de las prácticas mágicas según se llevaban a cabo en España resulta más útil la obra anterior publicada por Pedro Ciruelo titulada Reprobación de las supersticiones y bechicería, 1538. Este libro, mucho menos ambicioso que el de Del Río, resultó, sin embargo, más asequible y práctico, dado que uno de sus objetivos consistía en advertir a la gente sencilla de los peligros que conllevan las prácticas supersticiosas. 
La prueba que se presentaba en los procesos inquisitivos contra los acusados por estos crímenes podía revestir diferentes modalidades, predominando la testifical y la relativa a los objetos utilizados por los presuntos delincuentes en sus ceremonias y prácticas supersticiosas.

A lo largo de estas páginas vamos a prestar especial atención a estos últimos, por ser ampliamente expresivos de las creencias sobre las cuales se sustentaba una sociedad inculta gobernada por las autoridades desde la óptica de un severo paternalismo. Esos objetos materiales nos ilustran, además, acerca de muchos elementos que formaban parte de la vida cotidiana de los súbditos a lo largo de la Edad Moderna europea, resultando especialmente llamativa la uniformidad de las prácticas esotéricas en territorios geográficamente muy distantes.

Así pues, revisten especial interés los repertorios de objetos, actos, oraciones, ceremonias, etc., que se citan en los diferentes tratados dedicados a la persecución y castigo de los crímenes relacionados con el mundo esotérico.

Tales elementos, verdaderos indicios racionales de criminalidad, se enumeraban con mayor o menos meticulosidad dependiendo de los autores.

En las siguientes páginas se ofrecerán los distintos objetos reputados como mágicos por unos y como sospechosos de la herejía de los brujos y sortílegos por otros durante los siglos en que tales prácticas y creencias formaban parte del repertorio de los crímenes execrables. Especialistas en el delito de la brujería y otros que dedicaban sus escritos al Derecho penal en general no escatimaron esfuerzos a la hora de ofrecerles a los prácticos del mundo jurídico el apoyo teórico suficiente y necesario para extirpar esas creencias y castigar de manera ejemplar a quienes amenazaban gravemente el orden social establecido por los poderes civiles y religiosos desde el ámbito del ocultismo y la magia.

\section{LOS INDICIOS MATERIALES DE CRIMINALIDAD SEGÚN VARIOS TRATADISTAS}

La doctrina del Derecho penal general y también los especialistas en Derecho inquisitorial abordaron en no pocas ocasiones las pruebas e indicios en los que debían centrar su atención los jueces cuando se les presentaban hechos y actos relativos a los delitos de brujería y supersticiones. No en vano era uno más de los ilícitos susceptibles de ser perseguidos de oficio por las autoridades civiles y religiosas. 
Resulta extensísima la literatura acerca de estas cuestiones, de manera que en estas páginas no se pretende agotar todo lo que se escribió al respecto durante los siglos en que las prácticas mágicas se hallaban dentro del elenco de las actividades expresamente prohibidas por las leyes. Hemos seleccionados aquellos autores que contribuyeron a pergeñar las directrices básicas que habían de seguir quienes pretendieran luchar desde el ámbito jurídico contra lo que se consideraba una más de las plagas sociales que asolaban la España de la Inquisición.

El transcurso del tiempo reviste gran importancia en este caso debido a que la praxis de los delincuentes, si bien como tendremos ocasión de analizar no varió sustancialmente a lo largo de los siglos, fue adquiriendo nuevos matices. Ante la proliferación de esas prácticas a lo largo y ancho del continente europeo durante la Edad Moderna, se fueron ampliando los repertorios que contenían todos aquellos indicios susceptibles de ser considerados sospechosos por parte de los juzgadores.

Debido a la importancia que revistió su obra a lo largo de los siglos en que permaneció vigente la institución inquisitorial, comenzaremos por analizar los elementos que el tratadista medieval Nicolás Eymeric consideraba indicativos de la más que probable existencia de un crimen de herejía consistente en prácticas de brujería o supersticiones.

En 1231, el papa Gregorio IX instituyó la Inquisición medieval a raíz de los sucesos relacionados con unas herejías aparecidas con anterioridad a ese año en tanto en cuanto suponían un problema de orden público que conllevaba amenaza de secesión. Tales desviaciones suponían un serio reto para la propia autoridad política encarnada por aquel entonces en la figura de Federico II, a la sazón emperador del Sacro Imperio. Por ese motivo, a pesar de no haber demostrado este emperador demasiado interés en materia religiosa, la posible disidencia política de los herejes le hizo reaccionar contra quienes amenazaban el orden establecido. El pontífice, ante los atisbos de que fuera el poder civil y no el religioso quien asumiera la tarea de atajar esos brotes heréticos, nombró inquisidores con el fin de evitar que fuera el propio Federico II quien se entrometiera en materia de $\mathrm{fe}^{15}$.

Es en ese panorama donde irrumpe la figura de Eymeric. Este gerundense, doctor en cánones y teología, desarrolló su labor como teólogo e inquisidor general en la Corona de Aragón a lo largo del siglo XIv. Su vida,

${ }^{15}$ J. A. Fortea (ed.), Manual de Inquisidores..., op. cit., p. 19. 
no exenta de rasgos novelescos, le hizo permanecer durante varios periodos al borde de la heterodoxia y el cisma ${ }^{16}$.

Aunque fue una figura controvertida en vida, tras la muerte de este autor el Directorium Inquisitorum serviría como referencia y punto de arranque para todos teólogos posteriores que abordaron en sus tratados el delito de herejía ${ }^{17}$.

Si bien esa obra abarca muy diversos aspectos relativos a la institución inquisitorial, Eymeric hace especial hincapié en el delito de brujería, probablemente por el relieve que dicho crimen estaba adquiriendo cuando este autor redactó su Manual de Inquisidores. Incluso hay indicios de que había escrito previamente un tratado monográfico sobre ese tipo de herejía, ampliándolo posteriormente para transformarlo en su Directorium, obra de más amplio espectro. Su actividad inquisitorial le había proporcio-

${ }^{16}$ Nicolás Eymeric o Aymerich nació en Gerona hacia 1320. Allí ingresó en el monasterio de dominicos y durante su noviciado fue instruido en teología, completando luego sus estudios en Toulouse y en París, donde obtiene su doctorado en 1352. Regresa más tarde a Gerona ya como profesor de teología. En 1357, Eymeric es nombrado inquisidor general de Aragón. Un año después de obtener el puesto fue nombrado también capellán honorífico del papa en reconocimiento a su celo a la hora de perseguir herejes, lo cual también le granjeó bastantes enemigos, entre ellos el rey Pedro IV de Aragón. Esa enemistad determinaría que en 1376 Eymeric tuviera que huir de los territorios catalanes para refugiarse dentro de la corte papal de Gregorio XI en Aviñón. Fue allí donde redactó su más conocida obra, el Directorium Inquisitorum, alrededor de 1376. En los tiempos turbulentos durante los cuales fue papa Clemente VII, Eymeric se puso de su lado, regresando a Aviñón en 1378. Volvió a la Corona de Aragón en 1381, donde se encontró con que en su ausencia Ermengaudo lo había sustituido como inquisidor general. Pero él se negó a reconocer al recién designado. Su eterno enemigo, el rey Pedro IV, montó en cólera ante la soberbia desplegada por Eymeric y ordenó perseguirlo y darle muerte por ahogamiento, triste final del que lo salvó la intercesión de la reina Leonor de Sicilia, quien consiguió la conmutación de la primera sentencia por la de exilio perpetuo, sentencia que fue ignorada por Eymeric, permaneciendo en los territorios de la Corona de Aragón. Juan I, sucesor de Pedro IV, reconoció a Eymeric como inquisidor general de Aragón. Pero en 1388, Eymeric emprendió una investigación contra la ciudad de Valencia por herejía, dado que siempre se había mostrado contrario a las obras de Ramón Llull, ampliamente difundidas en esa población. Juan I tuvo que intervenir, rogando a las autoridades eclesiásticas que obligaran al dominico a moderar sus persecuciones. Ese es el motivo por el que hubo de desterrarse nuevamente a Aviñón, donde apoyó también por escrito al sucesor de Clemente VII, Benedicto XIII. Regresó a su monasterio dominico de Gerona tras la muerte de Juan I en 1396, lugar en que murió en 1399. En su sepultura reza la leyenda: praedicator veridicus, inquisitor intrepidus, doctus egregius.

17 Esa obra, primeramente impresa en Barcelona en 1503, ha sido recientemente traducida al castellano y prologada por José Antonio FORTEA (ed.), Manual de Inquisidores..., op. cit. Ya existían, sin embargo, otras versiones, como la traducción llevada a cabo por J. Marchena a partir del idioma francés que fue publicada en Montpellier (1821). Todo lo relativo a las invocaciones diabólicas se inserta en el Directorium, Parte 2, Quaestio 43, De invocantibus Daemones. 
nado gran cantidad de textos confiscados relativos a la magia, textos que eran utilizados por los que habían sido acusados de brujos y que circulaban comúnmente por toda Europa durante la Edad Media.

$\mathrm{Su}$ Directorium Inquisitorum nos ilustra acerca de bastantes prácticas mágicas y supersticiosas que se llevaban a cabo en los territorios donde él ejerció como inquisidor.

Este autor insiste en la consideración de la brujería como una forma perfecta de herejía, enseñanza que ya comenzara en el seno de la Iglesia desde que el pontífice Alejandro VI, a finales del siglo XIII, concedió autoridad a la Inquisición medieval sobre los brujos. Esa fue la política de las máximas autoridades eclesiásticas desde la mencionada época, por lo cual dicha competencia fue luego reconocida por Bonifacio VIII y Juan XXII. Así pues, no es de extrañar que las obras doctrinales ulteriores se refiriesen invariablemente a la brujería como delito del foro inquisitorial.

Tras hacer una brevísima enumeración de ciertos actos que pueden considerarse diabólicos, distingue Eymeric tres clases de delitos relacionados con la invocación al diablo en los cuales debería conocer el Santo Oficio, todo ello con referencias a los libros sagrados y a las obras de grandes teólogos de la cristiandad, tales como San Agustín y Santo Tomás ${ }^{18}$.

${ }_{18}$ N. Eymeric, Manual de Inquisidores para uso de las Inquisiciones de España y Portugal, ó compendio de la obra titulada Directorio de Inquisidores, de Nicolao Eymerico, Inquisidor general de Aragón, traducida del francés al castellano por D. J. Marchena, Montpellier, 1821, disponible en bttp://www.bibliothecasefarad.com/listado-de-libros/ manual-de-inquisidores-para-uso-de-las-inquisiciones-de-espana-y-portugal-o-compendio-de-laobra-titulada-directorio-de-inquisidores-de-nicolao-eymerico-inquisidor-general-de-aragon 1 (consultado el 3 de diciembre de 2020), pp. 98-99: «Los hechiceros y adivinos son procesados por el Santo Oficio, cuando en sus encantos hacen cosas que se rocen con heregia, como bautizar segunda vez las criaturas, adorar una calavera, etc. Mas si se ciñeren á adivinar los futuros contingentes por la quiromancia ó rayas de la mano, ó por el juego de dados, ó el aspecto de los astros, que son meras hechicerías, serán juzgados por los tribunales seglares. Los que dan pócimas amatorias á mujeres para que los quieran se asimilan á estos últimos (Directorium, Part. 2, Quaest. 52). En tercer lugar conoce el Santo Oficio de los que invocan al diablo, los cuales se dividen en tres clases. Los de la primera son los que le atributan culto de latría, sacrificándole, arrodillándosele, cantándole himnos, guardando castidad, ó ayunando en gloria suya, alumbrando sus imágenes ó dandoles incienso, etc. Los segundos se ciñen al culto de dulía ó hiperdulía, mezclando nombres de diablos con los de santos en las letanías, y rogándoles que sean sus intercesores con Dios, etc. Los últimos son los que invocan al demonio, dibujando figuras mágicas, poniendo un niño en medio de un circulo, valiéndose de una espada, una cama, un espejo, etc. [...] Todos cuantos invocan al demonio de cualquiera de los tres modos susodichos están sujetos á la jurisdicción del Santo Oficio como herejes, y deben ser castigados como tales (Directorium, Part. 2, Quaest. 43). Y efectivamente toda invocación al diablo de una de las tres especies que acabamos de indicar es acto de heregía, como quiera que se practicare (Directorium, Part. 2, Quaest. 43)». 
Por una parte, están los herejes que manifiestan adorar al demonio (dulia), realizando actos que solo deben ir dirigidos a la adoración divina, tales como reverencias, genuflexiones, cantar himnos u observar conductas tales como ayunar o guardar castidad en su honor. También poner velas o incienso a sus imágenes, etc. Según este autor, esos actos son indicio de adoración al demonio.

En un segundo apartado estarían quienes se limitan a venerarlo (latría), mezclando nombres de diablos con otros de santos en las letanías con la finalidad de que intercedan ante Dios para conseguir sus objetivos.

La tercera manera de manifestar trato con el demonio consistía en la mera invocación al diablo por medio de ceremonias tales como dibujar símbolos mágicos, poner un niño en medio de un círculo trazado sobre el suelo, usando una espada, una cama, un espejo, etcétera.

Siguiendo la pura tradición popular, el autor señala que esos invocadores diabólicos son fácilmente identificables «por su mirar horroroso y su facha espantable, que proviene de su continuo trato con el diablo» ${ }^{19}$. La idea de que cualquier apariencia repulsiva o desagradable está relacionada con el trato diabólico se perpetuaría a lo largo y ancho de Europa durante los siglos posteriores, haciendo estragos sobre todo entre las mujeres ajadas por la edad o por su estado de depauperación, así como entre las que padecían alguna deformidad física durante la etapa en que se llevaron a cabo las grandes cazas de brujas. Ello guarda relación con la conocida como marca del diablo, tan importante dentro del sistema penal acusatorio y felizmente rechazada por el sistema procesal inquisitivo.

No es, pues, demasiado amplio el elenco de objetos y actos indicativos de delito: rebautizar a los niños y adorar una calavera, honrar al diablo ofreciéndole sacrificios, postrándose ante él o cantándole himnos, ayunando o guardando castidad en su honor, poner velas o incienso ante sus imágenes, etc. También considera sospechosos ciertos actos como rezar oraciones en las cuales se entremezclan los nombres de santos y demonios. Dibujar círculos en el suelo y colocar en el centro a niños, así como el uso de objetos reputados mágicos por la tradición popular, tales como las espadas, los espejos, las camas, etc., también serían pistas que podrían conducir a la comisión de este tipo de delitos.

Ese elenco que ofrece Eymeric se constituiría en un sólido punto de partida que se iría ampliando a lo largo de los años en las obras de otros tratadistas de los siglos XVI y XVII, pero lo cierto es que, a juzgar por las

\footnotetext{
${ }^{19}$ Ibid.
} 
actas de los procesos inquisitoriales que se sustanciaron a lo largo de los siglos ulteriores, resulta evidente que seguían llevándose a cabo tales prácticas sospechosas ya reseñadas en el Directorium.

En cambio, no le parecía a Eymeric que hubiera herejía implícita en la práctica de la quiromancia o en el uso de los dados y la observación de los astros para adivinar lo que él denomina futuros contingentes. Tampoco darles pociones amatorias a las mujeres. Esas actividades las considera meras hechicerías que deberían ser juzgadas por los tribunales seglares ${ }^{20}$. Tampoco incurriría en herejía quien invocara al diablo para impetrar prodigios que son propios de su oficio, como, por ejemplo, que tiente a una mujer para que cometa pecado carnal ${ }^{21}$.

No es desdeñable la importancia que el autor les atribuye a las palabras que el presunto delincuente pudiera utilizar para invocar al diablo. Los vocablos que implican mera petición, súplica o ruego son claro indicio de herejía, pues podrían indicar que quien las profiere ha renegado de la suprema autoridad de Dios para reconocérsela al demonio. No ocurriría así con las expresiones que suponen un mandato o una orden dirigidos al propio maligno ${ }^{22}$.

También alude al pacto con el demonio, pues este no acudirá en ayuda de sortílegos y hechiceros a menos que se le ofrezca algo a cambio, según la doctrina que ya estableciera el papa Inocencio V.

Es interesante resaltar que la mayoría de los autores que teorizaron sobre los indicios del crimen de sortilegios heréticos, nunca cerraron la lista de los actos, palabras y objetos sospechosos de tales delitos. Así, Eymeric deja deliberadamente abierto tal repertorio añadiendo siempre a los ejemplos que ofrece un etcétera.

Redactó este autor su obra durante los tiempos en que proliferaban a lo largo y ancho de Europa los astrólogos y alquimistas, pretendidos científicos siempre bajo sospecha de tratos con el diablo para conseguir sus objetivos más o menos inconfesables. Aun concediéndoles en principio albergar buenas intenciones a la hora de intentar sus descubrimientos, afirma que la desesperación en que podrían incurrir al no lograr las metas

${ }^{20}$ Ibid., Directorium, Part. 2, Qu. 52 y 43.

${ }^{21}$ Ibid., Qu. 43. Sin embargo, dice el autor que si para ello el invocador hace uso de expresiones que impliquen adoración o súplica, debería ser considerado hereje.

${ }_{22} \mathrm{Ibid}$., p. 100: «Si el hechicero que invoca al diablo, por ejemplo, para que se enamore de uno una mujer se vale de los imperativos te mando, te apremio, te requiero, etc., no es tan esplicita su heregía; pero si dice te suplico, te pido, te ruego, etc., es herege manifiesto, porque estas formulas suplicatorias suponen y contienen adoracion implícita». 
que se proponían podría inducirles fácilmente a recurrir al demonio o a cometer delito de acuñación de moneda falsa con tal de alcanzarlas. Además, inserta una curiosa observación acerca de los alquimistas, de los cuales sospecha tratos demoniacos cuando se dedican a la alquimia sin tener previamente una considerable capacidad económica, siendo, pues, menos sospechosos los alquimistas acaudalados ${ }^{23}$.

Con ser importante la primigenia obra de Eymeric, la versión del Directorium Inquisitorum que se utilizó preferentemente por parte del Santo Oficio español fue la llevada a cabo por Francisco Peña en el siglo Xvi. Este autor nos ofrece el Directorium meticulosamente glosado y comentado muchos años después de que viera la luz en el siglo XIV ${ }^{24}$.

Insiste la obra glosada por Peña en los tres tipos de conductas sospechosas de tratos con el demonio, añadiendo a las iniciales expresadas dentro del Directorium original otras que abundan en las ya apuntadas en el mismo.

Serían indicios de adoración al diablo vestir de negro o de blanco para reverenciarlo o la ofrenda de sahumerios de ciertas plantas, así como los sacrificios de animales o ciertas partes de estos arrojándolos al fuego. También alude a la ceremonia consistente en arrojar sal en las llamas, del mismo modo que menciona especialmente la ofrenda de la propia sangre o la de animales ${ }^{25}$.

${ }^{23}$ Ibid.: «Los astrólogos y alquimistas pueden ser mirados como gente que invoca al demonio, porque cuando no consiguen los descubrimientos que desean acuden luego al diablo, sacrificandole victimas, con invocaciones tacitas ó espresas. La alquimia especialmente es ocasión próxima de que invoquen al demonio los que se dan á ella sin tener dinero, porque, si bien no es totalmente imposible que u rico procure hacer oro sin incurrir en sospecha de mágico, los alquimistas, que no tienen mucho caudal, como casi siempre se quedan pidiendo limosna despues de sus tentativas, dan las mas veces en llamar al diablo, ó en acuñar moneda falsa».

${ }^{24}$ Francisco Peña fue un fraile dominico nacido en la turolense Villarroya de los Pinares (1540). Estudió en Valencia y se doctoró en Derecho. Falleció en Roma (1570) tras glosar y publicar varias obras relativas a distintas cuestiones teológicas, entre ellas el Directorium Inquisitorum escrito por Eymeric dos siglos antes. Esa exitosa versión comentada vio la luz por vez primera en Roma (1570), siendo sucesivamente editada durante los siglos XVI y XVII. Tras la aparición de esta obra la edición impresa del Directorium aparecida en Barcelona (1503) quedó prácticamente inutilizada. En estas páginas se citará la edición de Venecia (1595).

${ }^{25}$ N. Eymeric y F. PeÑA, Directorium Inquisitorum, Venecia, 1595, disponible en bttps://books.google.es/books/ucm?vid=UCM5316847848Eprintsec=frontcoverEredir_esc $=$ $y \# v=$ onepage $\mathcal{E} q \mathcal{E} f=f a l s e$ (consultado el 14 de diciembre de 2020), p. 338: «De invocantibus Daemones»: «... vestibus nigris vel albis pro daemonis reverentia... De ambra, ligno, aloes et similibus aromaticis, subfumigando aves vel animalia alia inmolando; sanguinem propriam ex se emittere procurando; aves vel alia seu eorum partes comburendo; sal in ignem mittendo: holocaustum de quovis faciendo [...] sanguinem proprium $\mathcal{E}$ animalia offerendo» (Secunda pars Directorii, quaestio XLIII). 
En esta obra también se explica el delito en forma de dulia o veneración, menos grave pero igualmente digno de persecución y castigo. Consistía principalmente en entremezclar nombres de santos y demonios en las oraciones ${ }^{26}$.

Se añaden después ciertos objetos y ceremonias comúnmente utilizados por los sortílegos que, según ya se apuntaba en la obra primigenia de Eymeric, no son claramente indicativos de adoración ni de veneración al diablo. Los jueces deberían averiguar en esos casos el grado de herejía subyacente y las intenciones de quienes los utilizaban en sus conjuros. Se citan varios objetos clásicos como espejos, espadas o recipientes, así como la típica ceremonia consistente en colocar una criatura dentro de un círculo dibujado sobre el suelo mientras el sortílego lee ciertas oraciones en un libro para invocar a los demonios ${ }^{27}$.

Toda esa enumeración de indicios responde a la doctrina de los doctores de la Iglesia, doctrina que la versión Eymeric-Peña no olvida insertar en sus páginas ${ }^{28}$.

La antigua bula promulgada en su día por Juan XXII en 1326 titulada Super Illius Specula se añade a los anteriores contenidos en la obra de Eymeric-Peña debido a la importancia de la misma en lo que concierne a la persecución y castigo de los delitos de brujería y supersticiones ${ }^{29}$. La mencionamos aquí porque ya enumeraba varias acciones y ciertos objetos que implicaban pacto con el demonio. Algunos coinciden con los ya mencionados, como el uso de imágenes del diablo, espejos y recipientes. También cita el uso de anillos o cualesquiera otras cosas que se suelen usar para convocar a los demonios ${ }^{30}$.

${ }^{26}$ Ibid.: "Quidam aut daemones invocantes exbibent demonibus invocatis non honorem latria, sed dulia: ut pote nomina daemoniorum inter noia Spiritum Beatorum et Sanctorum in suis quibundam nefariis orationibus miscendo».

${ }_{27}$ Ibid.: "Quidam aut daemones invocantes, quaedam faciunt invocando in quibus non apparet clare, quod honorem nec latriae nec duliae exhibeant demonibus invocatis: ut circulum in terra describendo: puerum in circulo ponendo, speculum, ensem, amphoram vel aliud corpus pervium coram puero statuendo ipso necromantico librum tenente ac legente et demone invocante».

${ }^{28}$ Ibid., pp. 339-341. A lo largo de estas páginas se insertan las opiniones vertidas en las obras de san Agustín de Hipona o santo Tomás de Aquino, entre otros doctores de la Iglesia.

${ }^{29}$ Ibid., p. 341 . El papa Juan XXII sintió la necesidad de promulgar en 1326 esta decretal en la obra de N. EYMERIC y F. PEÑA titulada Extravagans Ioannis XXII contra Magos, magicasque superstitiones, ante la amenaza que suponía la proliferación de ciertas sectas diabólicas. En ella proclamaba la realidad de la brujería y el carácter herético de la misma.

${ }^{30}$ Ibid.: "Pactum faciunt cum inferno: daemones namque inmolant: hos adorant : fabrican ac fabricari procurant imagines: annulum vel speculum vel phialam, vel rem quamcumque aliam magice ad daemones inibi alligandos ab his petunt, responsa ab his recipiunt». 
En suma, debe resaltarse que a pesar del tiempo transcurrido entre el Directorium de Eymeric y la versión comentada por Peña, no son muchos los cambios experimentados en el seno de la doctrina en lo tocante a los indicios de este tipo de herejía. El comentario que Peña le dedica a lo que en su día fuera establecido por Eymeric se limita a esclarecer varias cuestiones relativas, sobre todo, a la consideración herética de esos delitos y a lo que debe entenderse cuando se refiere a los ritos y signos indicativos de adoración al demonio ${ }^{31}$.

Tras examinar la obra de Eymeric y los comentarios de Peña es importante resaltar la deliberada indefinición de los indicios que debían tenerse en cuenta para rastrear los crímenes propios del ocultismo. Ello dio pie a que todos cuantos trataron ulteriormente estas y otras cuestiones relacionadas con ese tipo de herejía fueran ampliando el elenco.

En el siglo XVI ve la luz otra obra de gran impacto en el continente europeo, así como específicamente en España. Se trata del Tractatus, de Grillando ${ }^{32}$. Buena parte de su obra se refiere a las distintas potestades del diablo $^{33}$, pero en ocasiones alude a los indicios concretos que deben servir como base procedimental para apreciar el crimen de brujería. Así, al hilo de su experiencia como juez papal para ese tipo de delitos, el citado autor hace especial hincapié en una constante que se observa en todos los territorios de la cristiandad, aludiendo a las palabras y oraciones supersticiosas generalmente pronunciadas por quienes hacían de las prácticas mágicas un modo de vida. Prácticamente en todos los expedientes inquisitoriales españoles instruidos para este tipo de delitos aparecen entremezcladas oraciones aparentemente ortodoxas para impetrar el auxilio de la Virgen y los

${ }^{31}$ Ibid., pp. 343-348, comentario 68. Peña desglosa, por ejemplo, cómo debe entenderse la castidad como adoración al diablo, los signos y palabras desconocidas realizados y pronunciadas en su honor, las penas que merecen los que invocan a los demonios, el concepto de superstición, los sortilegios amatorios, etc., todo ello insertando la doctrina de penalistas y tratadistas de la Inquisición cuyas obras no se habían publicado aún al tiempo del Directorium, por ejemplo, el Malleus Maleficarum, de Heinrich Kramer y Jakob SpRENGER (1486), o la de Jacobo DE Simancas, De Catholicis institutionibus (1569). Más adelante nos referiremos a esta última.

32 P. GRILLANDI, Tractatus de Hereticis et sortilegiis omnifariam coitu: eorumque penis, Lyon, 1536, disponible en bttps://babel.hathitrust.org/cgi/pt?id=ucm.5317952473Eview= 1upEseq=1 (consultado el 20 de diciembre de 2020). Este autor fue un jurista nacido en Abruzzo (Italia) alrededor de 1490. Se mostró muy activo en la corte del pontífice como juez especializado en juzgar delitos relacionados con la brujería desde 1517. Debido a esa experiencia procesal su Tractatus se convirtió en una obra de referencia en materia de brujería y demonología.

${ }_{33}$ Ibid., Libro II. 
santos con otras sapiens haeresim ${ }^{34}$. A menudo los sortílegos guardaban escritos conteniendo tales plegarias, si bien muchos de ellos simplemente las memorizaban. En el primer caso esos papeles se convertían en importantes indicios materiales del delito de brujería y supersticiones.

Este autor, en la línea de otros que se refirieron en sus obras a las ceremonias supersticiosas, consideraba la realización de esos sortilegios que se sirven de palabras santas como algo propio de las mujeres ${ }^{35}$.

También se refiere a ceremonias características de esos herejes, tales como la que consistía en bautizar ciertas imágenes, utilizarlas para sortilegios amatorios, etc. ${ }^{36}$ Por lo demás, Grillando no lleva a cabo una enumeración de los objetos materiales indicativos de sortilegio herético.

También fue ampliamente utilizada por los encargados de juzgar los crímenes relativos a la magia la obra de Torreblanca Villalpando ${ }^{37}$.

Se trata de un texto importante en cuanto a su alto nivel técnico. Se caracteriza por hacer especial hincapié en los distintos tipos de prácticas adivinatorias dentro del primer libro de los dos que componen el total de la obra. Distingue este autor multitud de artes utilizadas para adivinar lo que no se puede conocer de manera natural. Torreblanca plasmó en sus páginas una verdadera cruzada contra la astrología judiciaria, muy de moda en su tiempo ${ }^{38}$.

Al igual que otros tratadistas coetáneos y anteriores, alude a la adivinación fisionómica y a la quiromancia como sistemas de conocimiento que no deben ser totalmente rechazados ni refutados por concederles un cierto cariz científico, al relacionar algunas características físicas

${ }^{34}$ Ibid. En el sumario del Libro II el autor explica que debe entenderse por sortilegio propiamente dicho la invocación a los santos o a los apóstoles con fines adivinatorios, o las ceremonias y actos que se utilizan para conocer el futuro por medio de las Sagradas Escrituras.

${ }^{35}$ Ibid.: «Et hinc est quod isti incantatores et maxime mulieres in suis sortilegiis et incantationibus ut vulgariter dicit ut vulgariter dicit se pius dicere iubent per maleficiatum aut infirmum ave mariam vel pater nostrum aut alias similes orationes ad devotionem alicuius sancti, apostoli vel martyris».

${ }^{36}$ Ibid. Los títulos 10 y 11 del Libro II contienen lo relativo a la forma en que se ha de castigar a quienes bautizan imágenes o las utilizan para sortilegios amatorios.

${ }_{37}$ No existen muchos datos sobre la persona de Francisco TorReblanca VillalpanDo. Parece que fue un converso que se hizo religioso y se dedicó a escribir algunas obras sobre temas jurídicos. Publicó su obra más conocida titulada Epitome Delictorum sive de Magia in qua aperta vel occulta invocatio daemonis intervenit en Sevilla (1618) (en este trabajo hemos utilizado la edición de Lyon publicada en 1678), disponible en bttps://babel. bathitrust.org/cgi/pt?id=ucm.5317963888Eview=1up\&seq=7 (consultado el 7 de enero de 2021).

${ }^{38}$ Ibid., Libro I, caps. 7 y 8, pp. 33-39. 
con el estilo de vida de las personas que suelen llevar a cabo esas prácticas $^{39}$. Aunque alude luego a otros sistemas utilizados por los adivinos, tales como la cábala, la necromancia, la piromancia, la aerimancia, la hidromancia, la geomancia, la interpretación de los sueños y otro variado elenco de ceremonias consideradas supersticiosas, lo cierto es que poco añade a la ciencia de los indicios materiales que deben observar los juzgadores en la práctica procesal cotidiana.

Más interesantes a esos efectos son las observaciones que hace cuando se refiere, ya en el segundo libro de su obra, al sempiterno pacto con el demonio y a los elementos que pueden llevar a detectar la existencia del mismo ${ }^{40}$.

Aunque no fue una obra que revistiera gran éxito en su tiempo, debe ser mencionada la que elaboró fray Martín de Castañega ${ }^{41}$ debido a su repercusión posterior. Se trata de un texto en el que prima la obsesión por perfilar el icono de la brujería durante la Época Moderna. Lo hace con una notable ingenuidad si consideramos que otros tratados anteriores sobre la materia habían descartado ciertos poderes de las brujas que sí les concede este franciscano ${ }^{42}$. A través de la doctrina previamente vertida por algunos doctores de la Iglesia, como san Agustín y santo Tomás, rebate y condena los errores propios de la herejía supersticiosa.

Los asesinatos de niños o las libaciones de sangre humana, de honda raigambre en la tradición judeocristiana e incluso en las culturas paganas, donde el papel de vampiros lo desempeñaban algunas aves monstruosas de la mitología clásica, aparecen en la obra de Castañega como prácticas propias de quienes se ejercitaban en la brujería, siempre bajo los auspicios y el consejo del demonio ${ }^{43}$.

En lo tocante a los sanadores milagreros y supersticiosos, interpone Castañega una pretendida nota racionalista afirmando que no debe con-

39 Ibid., caps. 9 y 10 , pp. 56-67.

${ }^{40}$ Ibid., Libro II, caps. 5-9, pp. 166-184.

${ }^{41}$ Martín de Castañega fue un monje franciscano que escribió, por encargo de Alonso de Castilla, obispo de Calahorra, una obra contra los brotes supersticiosos y de brujería que habían surgido en su diócesis. Así es como surgió el Tratado de las Supersticiones, hechicerías y varios conjuros y abusiones, y de la posibilidad y remedio dellas, Logroño, Miguel de Eguía, 1529.

${ }^{42} \mathrm{Ibid}$. Utilizamos aquí una edición con estudio preliminar y notas de Fabián Alejandro Campagne, Universidad de Buenos Aires, Facultad de Filosofía y Letras, Colección de libros raros, olvidados y curiosos, 1997, disponible en bttps://www.researchgate.net/publication/266078458_Fray_Martin_de_Castanega_Tratado_de_las_Supersticiones_y_Hechizerias/ link/5534fedc0cf2ea51c13376bff/download (consultado el 8 de enero de 2021): «Capítulo VI. Cómo los consagrados al demonio pueden andar por los aires. Capítulo VII. Cómo en diversas figuras pueden andar y parecer los consagrados al demonio».

${ }^{43}$ Ibid., p. 86. 
siderarse efecto mágico lo que, aun escapando al conocimiento científico, puede ser explicado de manera natural y no como prodigio sobrenatural.

En aquellos tiempos durante los cuales se ignoraban los principios más elementales de las ciencias físicas que hoy explican los fenómenos magnéticos, señalaba este autor el ejemplo de la piedra imán como instrumento comúnmente utilizado por algunas sortílegas que afirmaban tener dicho mineral los poderes de atraer las voluntades de los hombres, haciendo para ello un experimento con agujas metálicas. Las mujeres ignorantes caían en la trampa de creer que era magia el movimiento de esas agujas puestas en proximidad del imán ${ }^{44}$. Lo mismo afirmaba respecto a otras piedras y sustancias naturales capaces de atraer ciertos materiales, cosa que ocurre, por ejemplo, con el ámbar o el azabache cuando se frotan con un paño debido a la electricidad estática ${ }^{45}$.

De este modo, con el fin de rebatir las propiedades mágicas de ciertos objetos, sustancias y rituales utilizados comúnmente por los sortílegos, nos informa Castañega de varios indicios de prácticas supersticiosas con tintes sospechosos de herejía.

El uso de yerbas y piedras, tan común entre los que practicaban la magia supersticiosa, se entremezcla con el de otros elementos que, sor-

44 Ibid., pp. 95-96: «Muchos tienen duda de la virtud y gracia que los saludadores tienen [...]. Para esto es de notar que las virtudes naturales son tan ocultas en la vida presente a los entendimientos humanos, que muchas veces vemos la experiencia y las obras maravillosas y no sabemos dar razón dellas, salvo que es tal la propiedad de las cosas naturales y que a nosotros es oculta, como es la propiedad natural y virtud oculta de la piedra imán, que atrae así al acero, como claramente parece por experiencia; y ninguno podría dar razón dello sino que es tal su propiedad. Yo conocí una mujer que engañaba a las mozas y mujeres simples con una piedra imán. Y decíales que ella haría que sus maridos y amigos las quisiesen tanto que no amasen a otras, y que nunca se apartasen dellas, y para esto tomaba aquella piedra, la cual por una parte no tenía virtud, y por la otra era muy fina, y diciendo algunas palabras y oraciones, porque pareciese cosa de conjuro, ponía sobre la palma de la mano o sobre alguna tabla una aguja de coser, que a la mujer que a esto venía le pidía y mostraba y ponía la piedra sobre la aguja en alguna distancia cuanto a dos dedos della, y después poníala más cerca cuanto a un dedo; y como no saltaba la aguja a la piedra, y aunque se tocasen no se juntaba con ella porque por aquella parte no era fina ni tenía virtud, luego le decía que su marido o amigo no la quería bien, mas por amor della y porque se lo gratificase, que ella haría un conjuro, que tanto la amaría que no se podría apartar della, y así tornaba a hacer su oración y decir ciertas palabras al propósito, y después tomaba la piedra y por la parte que tenía aquella virtud poníala como primero y algo más aparte sobre la aguja, y luego saltaba la aguja y se pegaba con la piedra y la llevaba consigo, y entonces creía la simple mujer, que no conocía la propiedad de la piedra, que donde primero no era querida quedaba muy amada de su marido o amigo».

${ }^{45}$ Ibid., p. 96: «Desta mesma manera el ámbar y el azabache no sudados, ni sucios, ni fríos, salvo con la ropa alimpiados y bruñidos, y con aquel movimiento escalentados, levantan y atraen as sí las pajuelas secas, en cuantidad proporcionadas». 
prendentemente, siguen siendo popularmente considerados como curativos o lenitivos en los tiempos actuales sin que para ello haya base científica alguna. Tal es el caso del cuerno de rinoceronte (que él denomina «unicornio»), al cual atribuye Castañega la propiedad de sanar en caso de envenenamiento. No niega el autor tales virtudes sanadoras de algunas sustancias y objetos, sino que se limita a atribuirlas a las propiedades naturales de los mismos ${ }^{46}$. Lo mismo, según él, sucede con la influencia de los astros en el cuerpo humano o con la saliva de algunas personas que es capaz de curar algunas enfermedades ${ }^{47}$. Todo tendría para él una explicación científica, aun concediendo que la ciencia no habría llegado a desentrañar el misterio de lo que en apariencia se trataría de un milagro. Esa interpretación sería contraria a la doctrina católica ${ }^{48}$.

De ese modo, Castañega, en una obra que no tuvo demasiado eco en su momento, se nos muestra como un adelantado a su tiempo en el sentido de atribuir a ciertas leyes físicas y químicas, las cuales él reconoce ignotas al momento de redactar su obra, muchos de los fenómenos que en aquella época venían siendo considerados como magia o milagro.

En lo tocante a las oraciones con efectos mágicos o a las supuestas virtudes de ciertas reliquias, también nos ilustra Castañega acerca de otras prácticas sospechosas hacia las que, hay que resaltar, se muestra bastante más tolerante que otros autores expertos en tales materias. Consideraba que no eran reprobables si se trataba de amuletos que contenían palabras del evangelio con dibujos y señales religiosas, tales como una cruz. Este autor consideraba que no debía sospecharse de quienes trajeran consigo semejantes objetos salvo cuando en ellos se expresara por escrito que

${ }^{46}$ Ibid., p. 96: «Y así se podría decir de muchas yerbas y piedras, y de la una que agora traen y usan en las sortijas para el mal del corazón; y del cuerno del unicornio para las ponzoñas, y otras semejantes cosas que tienen virtudes y propiedades naturales, que naturaleza imprimió en ellas».

${ }_{47}$ Ibid. Castañega se refiere concretamente a lo que sucede «cuando la luna está en conjunción con el sol», debiendo entenderse, según creencia común en su época y avalada también por algunos en la actualidad, que los eclipses influyen en el comportamiento y el cuerpo de los seres vivos, ya se trate de personas o animales. Sobre la saliva y sus efectos curativos, generalmente atribuidos también a un milagro divino, mantiene este autor que: «Tienen algunos hombres tal saliva en ayunas que basta matar las serpientes; y cada día vemos que la saliva en ayunas cura las sarnillas y algunas llagas sin aplicar otra medicina».

48 Ibid., pp. 96-97: «Otramente a cada paso teníamos necesidad de atribuir tales obras a milagro. Lo cual es contra los doctores católicos, que nunca jamás habemos de decir que sea milagro cosa que naturalmente (aunque por virtudes a nosotros ocultas) se puede producir, porque el milagro es obra que la virtud natural no tiene fuerzas para la obra ni lo hemos de otorgar si no fuéremos constreñidos por necesidad, faltando la potencia y virtud natural». 
quienes los portaran quedarían mágicamente libres de algunos tipos de muerte violenta ${ }^{49}$.

También excluía Castañega de las prácticas sospechosas las consistente en utilizar el agua del lavatorio del cáliz para beberla o derramarla sobre los ganados enfermos, considerando este acto mera devoción, lo mismo que cuando se solicitaba una porción del aceite ofrecido a los santos ${ }^{50}$.

Mucho más intolerante se mostraba este fraile con los conjuradores que pretendían tener el poder de controlar los desastres meteorológicos. El propio Castañega nos ilustra acerca del panorama que a este respecto se vivía en su época, afirmando que existía una enorme proliferación de individuos con presuntas habilidades para conjurar las tempestades tan temidas por dar al traste con las expectativas de muchos agricultores. Según nos cuenta este autor, estos personajes gozaban del favor popular y disfrutaban de plaza fija y retribuida en la mayoría de las poblaciones. Allá donde aparecían se ofrecían a librar a los habitantes de la amenaza constante del pedrisco. Denuncia, además, que muchas veces desempeñaba el oficio de conjurador el cura de la localidad. Al parecer, había una gran competencia entre los conjuradores de vientos y tempestades, llegando a apostarse entre ellos quién sería el que gozaba de mayores poderes al efecto, lo cual nos hace sospechar que se trataba de una profesión que podía producir pingües beneficios. Quienes desempeñaban tales tareas admitían en muchos casos sus tratos con ciertos demonios para determinar en qué zona quedarían librados de la tempestad y dónde debía dirigirse la nube para descargar su hielo. El trato diabólico se ponía de manifiesto, entre otras cosas, por la frecuencia con que estos conjuradores recurrían a dibujar círculos en el suelo introduciéndose en los mismos para realizar sus conjuros, práctica altamente sospechosa de herejía, como ya se ha mencionado anteriormente ${ }^{51}$.

${ }^{49}$ Ibid., Cap. XVI, «De las nóminas y reliquias no supersticiosas ni sospechosas», p. 131: :«Y más si en la nómina se pone que quien la trajere no morirá en agua, ni fuego, ni en parto, ni en armas, y semejantes palabras; o si hay en ellas algunas figuras, salvo la cruz, $\mathrm{o}$ algunas palabras fuera de las que se usan en la Iglesia».

${ }_{50}$ Ibid., p. 132.

${ }^{51}$ Ibid., Cap. XIX, «De los conjuradores e conjuros supersticiosos de las nubes y tempestades», p. 165: «Los conjuradores y conjuros de las nubes y tempestades son tan públicos en el reino que, por maravilla, hay pueblo de labradores donde no tengan el salario señalado y una garita puesta en el campanario, o en algún lugar muy público y alto, para el conjurador, porque esté más cerca de las nubes y demonios. Anda este error tan desvergonzado que se ofrecen a guardar el término de la piedra de aquel año, y toman porfía y apuestan sobre ello con otros conjuradores comarcanos (y estos tales muchas veces son los curas de los lugares) y al tiempo de los conjuros dicen y lóanse que juegan con la nube como con una pelo- 
No tiene desperdicio la glosa seudocientífica con que Castañega pretende desprestigiar a esos que él considera charlatanes, pues al parecer explicaban que convertían el granizo en agua con sus conjuros, cuando en realidad, según él nos explica con una deliciosa ingenuidad, el proceso es el contrario, siendo primero agua y luego granizo ${ }^{52}$.

Arremete también contra el uso de palabras hebraicas y griegas por parte de tales conjuradores, acusándolos de utilizarlas para producir el asombro de todos los presentes en sus ceremonias ${ }^{53}$. Esos vocablos también serían considerados de alto contenido herético por parte de los inquisidores, constituyéndose en graves indicios de los delitos de brujería y supersticiones.

En suma, la obra de este autor tiene una importancia relativa que debe ser puesta en relación directa con la de Pedro Ciruelo, tratadista que, aun siguiendo sus pasos muy de cerca, adquirió una notoriedad muy superior por la mayor enjundia y profundidad jurídica de su obra titulada Tratado en el qual se reprueban todas las supersticiones y hechizerías ${ }^{54}$. Esta obra fue objeto de numerosas ediciones.

ta, sobre quién a quién se la echará en su término; y algunos, que presumen de más sabios, hacen cercos y entran en ellos, y dicen que se ven en tanta priesa con los demonios que les echan el zapato de pie, para que con él se despidan; y salen del cerco muy fatigados, y lóanse de muy esforzados, y señalan términos dentro de los cuales quieran que se extiendan y valgan sus conjuros, procurando de echar la nube fuera de su término, y que caya en el de su vecino o en tal lugar y parte señalada. Todo lo cual, cuanto sea vano, malo, supersticiosos y diabólico, cualquiera que recto juicio tenga lo puede conocer. Las locuras, simples necedades que dicen son para reír, y aun para reñir».

${ }_{52}$ Ibid., p. 166: «Si fuesen (los conjuradores) filósofos naturales sabrían cómo la piedra, que ellos temen, primero es agua y después se congela en piedra, [...] y de esta manera que por el grande calor del aire propincuo encógese y fortifícase la frialdad del agua, que cae como huyendo de su contrario, en tanta manera que se congelan las gotas del agua, que descienden se endurecen y se hacen piedra en muy poco espacio de tiempo y cuasi súbitamente [...] Esto se hace comúnmente acá abajo en la ínfima región del aire que es caliente, y cerca de la tierra. En señal desto suele apedrear en los días muy destemplados de calor, y después de medio día, cuando más arde el sol, andando muy baja la nube negra, de que apedrea cerca de la tierra, y cuando algunas veces caen las piedras mezcladas juntamente con gruesas gotas de agua, es señal que no basta el calor para congelar, en la manera sobredicha, todas las gotas en piedras».

53 Ibid., p. 167: «Ensartan (los conjuradores) sin orden y sin concierto multitud de palabras y dicen, haciendo los signos, como amenazando a la nube [...] e añaden con una confusión babilónica Eli, eli, lamazabathani, agla, aglata tetragrammaton, Adonay, agios o theos [...] y cuantos nombres hebraicos y griegos e incógnitos pueden hallar, como si en los vocablos que no entienden se encerrasen mayores secretos y misterios, y toviesen más virtud».

${ }_{54}$ P. Ciruelo, Tratado en el qual se reprueban todas las Supersticiones y Hechizerías: muy útil y necessario a todos los buenos Christianos zelosos de su salvación. Su obra fue publicada inicialmente en Alcalá de Henares en 1538. Este autor estudió en Salamanca, donde 
Ciruelo, tras explicar cuántas clases de supersticiones existen ${ }^{55}$, comienza a explicar los instrumentos de los cuales se sirven las personas para practicarlas. El primer paso consiste en invocar al demonio para obtener su ayuda a la hora de obrar los pretendidos prodigios. Ello se logra por medio de palabras y ceremonias, además de ofrendas similares a las que se llevan a cabo durante la celebración de la misa, sobre todo de pan y vino, así como de otras viandas y sahumerios en que se mezclan hierbas y perfumes ${ }^{56}$.

Una vez que el diablo recibe esas preces y oraciones, los nigromantes se podrían comunicar inmediatamente con él por medio de los consabidos métodos tradicionales ya mencionados en las obras de otros tratadistas. Se ofrece así una enumeración de objetos reputados como mágicos desde épocas remotas. Tales serían el círculo dibujado en el suelo, el recipiente conteniendo agua, los espejos, las piedras preciosas, los anillos etc. Incluso menciona un método peculiar que no encontramos en otros tratados. Se refiere al aspecto de las propias uñas del sortílego. De todos modos, Ciruelo deja abierta la lista de las ceremonias y los objetos que pueden ser utilizados para perpetrar tales crímenes supersticiosos ${ }^{57}$.

No olvida este autor referirse específicamente a las artes utilizadas por las brujas para pretendidamente volar por los aires y hacer sus maleficios, consistiendo sus conjuros sobre todo en el uso de ungüentos y ciertas palabras u oraciones ${ }^{58}$.

Las artes adivinatorias son objeto de mención especial en la obra de Ciruelo. Enumera siete en total. La primera, conocida como geomancia, se llevaba a cabo trazando ciertos signos escritos en la tierra o en el papel. La segunda es la bidromancia. En esta modalidad los adivinos solían derre-

se licenció. Más tarde marchó a París, donde se doctoró en teología. Se trata de un hombre de vastos saberes que cultivó ciencias tan diversas como las matemáticas, la filosofía, la música y la teología. Murió siendo canónigo magistral en la catedral de Salamanca. Hombre de una portentosa erudición, fue preceptor, entre otras figuras históricas de importancia, del rey Felipe II.

55 Ibid. En este estudio utilizamos la edición de Barcelona (1628), disponible en bttp:// www.cervantesvirtual.com/obras/autor/ciruelo-pedro-18096 (consultado el 15 de enero de 2021), pp. 38-39: «Quedan luego reduzidas todas las supersticiones a quatro especies principales y son estas, nigromancia, adevinación, ensalmo y hechizería».

56 Ibid., p. 44: «Y el demonio tiene concertado con ellos por estos servicios que le hacen que con estas ceremonias les aparecerá y hablará por palabras o por señas con que se entiendan».

${ }^{57}$ Ibid.: «Y an algunos dellos en la vizlumbre de las uñas de sus manos y de otras infinitas maneras».

${ }^{58}$ Ibid., p. 45. 
tir plomo, cera o pez sobre un vaso lleno de agua, observando luego las figuras que forman esos materiales al solidificar para adivinar aquello que pretendían conocer. Menciona también la adivinación por medio del aire o aerimancia, consistente en conocer el futuro prestando atención al sonido que hace el viento cuando bate las hojas de los árboles o cuando se introduce por los resquicios de las casas, puertas y ventanas. También se podía intentar adivinar el futuro por medio de la piromancia, que utilizaba las llamas y su colorido, así como el sonido que hicieran mientras permanecía encendida la hoguera. La quinta especie adivinatoria es la llamada spatulamancia, que se valía de los huesos dorsales de animales muertos puestos en el fuego para observar si saltan o la parte por donde se quiebran. La sexta arte adivinatoria es la quiromancia, vigente hasta nuestros días, según la cual se puede conocer el porvenir por las rayas de la mano. En este caso el autor se extiende explicando las razones por las cuales no debe considerarse eficaz, basándose principalmente en razones de tipo fisiológico. Sin embargo, admite las teorías científicas vigentes en su época según las cuales por las líneas de la mano sí se podría saber la constitución interna de ciertos órganos tales como el cerebro, el estómago, el corazón o el hígado. Por último, alude al arte sortiaria, consistente en la adivinación por suertes que se pueden echar de varias maneras, citando Ciruelo a modo de ejemplos los dados, los naipes, salmos de la Biblia, cedazos, tijeras y otros objetos ${ }^{59}$.

Varios de los objetos mencionados por este autor, especialmente los dados, naipes, cedazos y tijeras, fueron de uso muy común entre los sortílegos españoles, a juzgar por los diversos expedientes inquisitoriales en que se menciona su utilización, pero también se usaban en otros muchos territorios europeos.

Los conocidos como cédulas, también eran objetos que hacían sospechar la práctica de supersticiones heréticas por parte de quien los portaba o utilizaba. Aparentemente consistían en oraciones u otros escritos y dibujos generalmente relacionados con la astrología. Solían plasmarse en pergamino virgen. Los colocaban en las puertas de la casa para atraer las riquezas o incluso en los terrenos de cultivo para conseguir mejores cosechas, en el corral del ganado para protegerlo de las enfermedades, etc. A este respecto parece haber sido práctica común llevar este tipo de amuletos con dibujos considerados mágicos o con trazos reproduciendo constelaciones y astros con el fin de atraer hacia sí el favor de los poderosos. Tenían que

${ }^{59}$ Ibid., pp. 68-70. 
plasmarse sobre ciertos materiales valiosos que, al igual que en algunas prácticas esotéricas actuales, se relacionan con los astros ${ }^{60}$.

Los sortilegios que pretenden dañar al prójimo también tienen cabida en esta vasta obra. Se mencionan las temidas ligaduras y los aojamientos, consistentes las primeras en ataduras hechas en cordones o cuerdas generalmente con la intención de inhabilitar a los casados para el coito, aunque también podían ir dirigidas a producir algún tipo de discapacidad en los miembros de otras personas, causar enfermedades, etc.; los aojamientos, como su nombre indica, causaban un daño determinado simplemente por medio de la mirada del sortílego dirigida hacia la víctima del maleficio ${ }^{61}$.

Dedica este autor varios capítulos a otras creencias supersticiosas comúnmente asumidas también por algunos en la actualidad. Se rebaten así los llamados días aziagos, tradición arrastrada desde la Antigüedad clásica $^{62}$. Los exorcismos fuera de lo preceptuado por la Iglesia también son considerados en su obra como abusos para engañar a las personas ingenuas ${ }^{63}$. Al igual que ya se vio en la obra de Castañega, arremete Ciruelo contra los pretendidos conjuradores de las tempestades ${ }^{64}$.

Especialmente peligroso consideraba este autor el uso de oraciones ortodoxas y piadosas cuando se entremezclaban con ciertas prácticas supersticiosas, pues el diablo usaba de su astucia para engañar a las personas haciéndoles creer que no hay maldad en ello. En estos casos quienes debían calificar tales delitos debían ser expertos teólogos debido a la sutileza que ocasionalmente encerraba la forma en que estaban compuestos esos rezos ${ }^{65}$.

${ }^{60}$ Ibid., p. 102: «Otros atraen consigo cédulas pintadas de algunas figuras y caracteres escritos de la arte mágica, o de la astrología, para tener gracia y favor con algunos señores para medrar por allí. Y los caracteres están figurados en pergamino virgen o en oro, o plata, o en otro metal hechos quando reinava la constelación del signo o planeta a quien se atribuye aquel metal, que dicen que el oro se atribuye al sol, la plata a la luna, el plomo a Saturno, \&c».

${ }^{61}$ Ibid., p. 140: «Para ligar a los casados, que el marido y la mujer no se puedan conocer ni hazer generación, o para tollir o baldar a otro de algún braço, pierna, y aun de todo un lado o de todo el cuerpo, o para le hazer caer en alguna grande enfermedad, y a este propósito viene lo que comúnmente dizen que unos aojan a otros, quieren dezir que los dañan con el ojo quando de hito los miran».

${ }^{62}$ Ibid., Parte tercera, Cap. VI, «Disputa contra la fantasía de los días aziagos».

${ }^{63} \mathrm{Ibid}$., Cap. VIII, «De los sacadores de los espíritus malos en las personas que están endemoniadas».

${ }^{64}$ Ibid., Cap. IX, «Disputa contra los comunes conjuradores de los nublados en tiempo de tempestad».

${ }^{65}$ Ibid., Cap. XI, «De las oraciones que se hacen con ceremonias vanas y supersticiosas». 
En suma, afirma Ciruelo que todos esos objetos y prácticas no tienen poder alguno para obrar prodigios, siendo, por el contrario, grave indicio de tratos con el demonio ${ }^{66}$.

A lo largo de su obra, Ciruelo ofrecía una base sólida para relacionar las prácticas que reseña en sus páginas con los delitos de brujería y supersticiones, razón por la cual fue utilizada a lo largo y ancho del continente europeo tanto por parte de los tribunales inquisitoriales como por otros de signo laico que llevaron a cabo las conocidas cazas de brujas, siendo su tratado objeto de múltiples ediciones.

Diego de Simancas ${ }^{67}$ en su obra De Catholicis Institutionibus dedica especial atención al concepto de superstición y a la competencia de los inquisidores para juzgar ese tipo de delito. En cuanto a lo primero, no difiere de lo que ya se estableció anteriormente por otros autores como Grillando, pues considera sortílegos a quienes llevan a cabo prácticas adivinatorias por medio de invocaciones piadosas a los santos ${ }^{68}$.

Según este autor, los tratos con el demonio caen dentro del ámbito de la idolatría, que debe ser catalogada como herejía formal si resultaren debidamente probados por los inquisidores.

En cuanto al elenco de indicios que deben conducir a sospechar relaciones con el diablo, tampoco llega a concretar Simancas un repertorio de los mismos, sino que ofrece sobre todo la doctrina establecida por los padres de la Iglesia, remontándose también con frecuencia a la Antigüedad clásica. Muestra especial interés en su obra por las supersticiones consistentes en la interpretación de los sueños para adivinar el futuro, cosa que ya era practi-

${ }^{66}$ Ibid., p. 103: «Queda luego que todas estas cosas no tienen virtud natural para hazer los efectos que quieren los mundanos. Y ansí aplicarlas para ellos es vanidad y superstición diabólica [...] sepan de cierto que en ello ofenden a Dios y sirven al diablo con quien tienen pacto secreto de amistad [...] y quererlas aplicar a lo que no pueden hazer es consentir en la amistad del diablo, que es apostasía contra la religión Christiana, y poco menos es que renegar la Fe».

${ }^{67}$ Diego de Simancas nació, al parecer, en Córdoba, si bien estudió en Salamanca llegando a enseñar en la Universidad de Valladolid. Fue famosa su intervención en la causa que se siguió entre 1559 y 1567 contra el arzobispo Carranza por delegación del inquisidor General Valdés. Su obra más conocida es la titulada De Catholicis Institutionibus Liber ad Praecavendas \& Extirpandas haereses admodum necessarius (1554). En el presente trabajo se ha utilizado la edición complutense de 1569, disponible en bttps://babel.hatbitrust.org/cgi/ pt? id $=u \mathrm{~cm} .5316850711$ Eview $=1$ up Eseq $=5$ (consultado el 20 de enero de 2021).

${ }^{68}$ J. Simancas, De Catholicis Institutionibus Liber ad Praecavendas E Extirpandas haereses admodum necessarius, Alcalá de Henares, 1569, Tit. LXII, 1: «Sortilegi qui sunt: Sortilegi sunt qui sub nomine Sanctae religionis per quasdam sortes quas apostolorum vel sanctorum vocant, divinationis scientiam profitentur. Item illi sortilegi sunt qui quarumque scripturarum fortuita inspectione future paraedicunt $\gg$. 
cada en la antigua Roma ${ }^{69}$. Prefiere, pues, Simancas atribuir ciertos sueños peculiares a causas naturales o a los engaños del diablo.

También se manifiesta en lo referente a la vieja superstición que ha sobrevivido hasta nuestros días relativa a la existencia de ciertos días desafortunados de la semana, haciendo mención expresa de los martes y los viernes como días reputados nefastos. La cultura occidental se ha repartido geográficamente tales días, prefiriéndose el viernes en los territorios anglosajones y los martes en la cuenca mediterránea ${ }^{70}$.

Alude este autor a ciertos elementos que ya fueron mencionados anteriormente en la obra de otros tratadistas cuando hace referencia al pacto implícito con el diablo, que puede ser invocado por medio de figuras, palabras, caracteres y signos desconocidos de tipo supersticioso, siempre y cuando esos actos se lleven a cabo con la intención de lograr aquello que se sabe puede proporcionarlo el demonio ${ }^{71}$.

La adivinación del futuro por medio de la observación de los astros se consideraba herejía consumada en la obra de Simancas ${ }^{72}$.

Lo cierto es que este tratadista no ofrece ningún repertorio de objetos que deben ser reputados diabólicos, más bien alude a ceremonias y actos.

También se refiere, como otros autores anteriores, al uso de signos, figuras, palabras y caracteres desconocidos cuando condena el pacto implícito con el demonio llevado a cabo con el fin de lograr ciertos efectos que la ortodoxia consideraba podían ser procurados por el diablo a favor de las personas que llevaran a cabo el susodicho acuerdo ${ }^{73}$.

No olvida incluir este autor algunas alusiones a ciertas supersticiones que se practicaban con frecuencia en su época, habiendo algunas de ellas sobrevivido hasta nuestros días. Ese es el caso de las mencionadas ligaduras

${ }^{69}$ Ibid., Tit. LXIII, 5: «Non est igitur somniis habenda fides [...] quia vana sunt $\varepsilon$ ex repletione aut vacuitate, atu egritudine, aut illusione demonum, aut ex causis naturalibus, eorum imagines phantasmasta provenire solent».

${ }^{70}$ Ibid., 6: «Qui putant dies quosdam fortunatos, alios infoelices ese, hi proculdubio vehementer errant. Neque enim ratio reddi potest, cur magis infausti sint dies martis $\mathcal{E}$ veneris, aut quidam alii, quam caeteri dies: Deus etenim eodem modo fecit hos atque illos dies».

${ }^{71}$ Ibid., 12: «Quo sit [...] figuris, characteribus, verbis \& signis ignotis E superstitiosis, idque ad aliquem effectum qui noscitur ex diabolo provenire vel etiam cum aliquies talibus rebus se implicat, qualibus dignum est ut se daemonorum immisceat, quamvis id eveniat praeter hominis intentionem».

72 Ibid., 7: «Est E alia superstitio eorum, qui ex sideribus \& cometis, E facibus caelestibus futura praedicunt: quorum omnium impia temeritas coercenda $\&$ reprimenda est [...] hi enim consummati heretici sunt».

${ }_{73}$ Ibid., 8: «Quo sit, ut nonnunquam tacite invocetur demon figures, characteribus, verbis E signis ignotis \& supersititosis, idque ad aliquem effectum qui noscitur ex diabolo provenire». 
o «amarres», hechizos amatorios que suelen consistir en hacer nudos en un cordón, generalmente para asegurar el afecto del ser amado o para maleficiar a alguien dejando a esa persona impotente o estéril para la procreación. Los llevaban a cabo los sortílegos generalmente por encargo de sus «clientes». También eran corrientes los remedios de los sanadores que no tenían ninguna base científica, habiendo sido tales remedios condenados por los médicos. Tanto las primeras como los segundos resultan catalogados por Simancas como supersticiones. Así, serían indicios de delito ciertos cantos y oraciones, el uso de objetos suspendidos, tales como pendientes o anillos, o el sujetar el pulgar del pie izquierdo con la mano derecha ${ }^{74}$.

Mucho menos frecuentes son otras prácticas recogidas por este autor recordando las que ya se prohibieron en el Antiguo Testamento o en la Roma clásica ${ }^{75}$. Termina Simancas concluyendo que todos aquellos que pretendieran lograr efectos que no se pueden conseguir de manera natural incurrirían en superstición que debe ser puesta en relación con un pacto diabólico, de modo que sus actos habrían de considerarse propios del foro inquisitorial, estando abocados a diversos castigos tales como la flagelación, la pena de galeras o incluso la relajación ${ }^{76}$.

Ya antes se ha mencionado a Martín del Río, jesuita de origen español, aunque nacido en Flandes, cuya obra tuvo un importante impacto en el tratamiento jurídico que se les dio a los crímenes relacionados con la magia ${ }^{77}$. En sus Disquisitionum Magicarum libri sex Del Río relaciona directamente la brujería con la herejía. Dado que se utilizó tanto por parte

${ }^{74}$ Ibid., 19: «Ad genus quoque superstitionum pertinent omnes ligaturae atque remedia, quem medicorum etiam disciplina condemnat: sive in quibusdam notis, quas characteres vocant, sive in quibuscumque rebus suspendendis atque ligandis, sicut sunt in aures, ut summo singularium aurium, aut destruthionum ossibus ansulem in digitis, aut cum dicitur tibi singultienti, ut dextera manu sinistrum policem teneas. In his omnibus ars demonum est, ex quadam pestifera societate hominum E angelorum malorum exorta».

${ }_{75}$ Ibid., 23-30.

76 Ibid., 33: «De suprascriptis autem omnibus aliisque, multis observationibus, haec generalis doctrina traditur. Ea quae naturaliter illos effectus producere nequeunt, ad quos efficiendos adbibentur, superstitiosa sunt, E pertinent ad pacta demoniorum [...] Proinde observare nomina, signa, caracteres $\&$ caetera omnia, quem natura sua nullam virtutem habent, superstitiosum est [...] 34 Inquisitores punire debent, superstitiosos istos prestigiatores, magos planetarios, excantatores, augures, E id genus alios qui iuste plerumque flagellis cesi ad remos mittendi ut certe relegandi sunt».

77 R. MADRID, «El delito de brujería en el Libro segundo de las Disquisitionum Magicarum de Martín del Río», Teología y Vida, vol. 56, núm. 4 (2015), pp. 351-377, disponible en https://www.researchgate.net/publication/293799661_El_delito_de_brujeria_en_el_ Libro_Segundo_de_las_Disquisitionum_Magicarum_de_Martin_del_Rio (consultado el 20 de enero de 2021). 
de las autoridades católicas como protestantes, se sabe que esta obra fue un importante elemento de apoyo y consulta a lo largo de los procesos que tuvieron lugar en Salem a finales del siglo XVII ${ }^{78}$.

Comienza la susodicha obra ofreciendo una interpretación particular acerca de la propia etimología de la palabra superstición, de la que se han señalado diferentes significados. Al respecto, algunos la habían relacionado con los tiempos de la Roma clásica, cuando los padres rezaban a los dioses para que sus hijos les sobreviviesen, que les fueran «supérstites», al considerarse ya por aquel entonces una de las mayores desgracias la premoriencia de los descendientes. El autor ofrece diversas variantes sobre la relación entre las prácticas supersticiosas y el crimen que procede a diseccionar, desde quienes relacionan el término con «stare supra» en clara alusión a los asuntos celestes o divinos, pasando por los que creen ver delirios propios de quienes han alcanzado edades avanzadas, si bien parece que prefiere la etimología que ofrecía san Isidoro ${ }^{79}$.

Una vez más y en la línea de otros coetáneos, este autor no nos ofrece una panorámica sistematizada de los indicios materiales que deberían considerarse a la hora de sospechar la existencia del crimen relacionado con la magia. Sin embargo, el rastreo de los mismos a lo largo de la obra nos proporciona un elenco bastante exhaustivo de los elementos comúnmente utilizados en los delitos de sortilegios y brujería, convirtiéndose, por ello, en un trabajo de referencia digno de ser tenido en cuenta por diferenciarse de otros que no descendían a la forma de materializarse tales crímenes en el marco de la realidad cotidiana, quedándose en puras abstracciones de tipo teológico o filosófico. De ahí, probablemente, su éxito editorial.

${ }^{78}$ Martín Antonio del Río nació en Amberes (1551). Era descendiente de españoles, jesuita y doctor en leyes por la Universidad de Salamanca. Su título lo habilitó para enseñar teología en varias universidades centroeuropeas. Su obra más famosa es la titulada Disquisitionum magicarum libri sex, relativa a los crímenes de magia. Fue publicada por vez primera dividida en tres partes en el año 1599, siendo reimpresa en numerosas ocasiones hasta mediados del siglo XvIII por la utilidad que les proporcionaba a las autoridades implicadas en las cazas de brujas que tuvieron lugar en Europa y América durante el amplio periodo que abarcan los siglos XVI y XVII. En este trabajo se ha utilizado la edición publicada en Venecia (1640), disponible en https://books.google.es/books/about/Disquisitionum_magicarum_ libri_sex.html?id=VEDIwQEACAAJEredir_esc=y (consultado el 1 de febrero de 2021).

${ }_{79}$ M. DEL Río, Disquisitionum magicarum libri sex, Venecia, 1640, L. I, cap. 1: «De superstitione et eius speciebus: Etymologiam nimis curiose div. Isidorus scrutatur his verbis: superstitio dicta eo quod sit superflua, aut superstatuta observatio. Alii dicunt a senibus, quia multis annis supérstites per aetatem delirant et errant superstitio quadam, nescientes quae vetera colunt aut quae veterum ignari asciscunt. Lucretius antem superstitionem dicit superstantium rerum, id est coelestium seu divinarum quae super nos stant». 
A pesar de ello, la sistemática interna dista de ser meticulosa, como lo demuestra el hecho de dividirse algunos libros en capítulos y cuestiones, mientras que en otros no aparece la distribución de las materias por capítulos, entrando directamente a enumerar las cuestiones.

Pero, ¿cuáles son esos indicios materiales que aparecen reseñados en la obra de Del Río?

Algunos se refieren a ciertos textos que aluden a personajes bíblicos sospechosos siempre de albergar intenciones heréticas. Por ejemplo, los escritos del rey Salomón, figura que aparece en cantidad de conjuros supersticiosos $^{80}$. El autor entiende que detrás de tales textos y sus invocaciones generalmente interviene pacto con el demonio. Frecuentemente los sortílegos y hechiceros llevaban consigo papeles o pergaminos con esos escritos sapiens haeresim o con «olor a herejía», razón por la cual solían registrarse las ropas y los domicilios de quienes eran acusados de esos crímenes e incluso de los presuntos maleficiados.

Por supuesto, se rechazan los efectos milagrosos de ciertas hierbas, a las cuales este teólogo solamente les concede efectos naturales en nada relacionados con la magia. Estas plantas aparecen reseñadas conjuntamente con los minerales que se utilizaban como sanadores e incluso a modo de objetos útiles para conculcar los fenómenos naturales, sirviendo, por ejemplo, para propiciar la lluvia. Especial tratamiento se le da a la piedra imán, un clásico entre los artículos frecuentemente utilizados por los sortílegos con multitud de aplicaciones y que el susodicho autor menciona separadamente de otros minerales ${ }^{81}$.

En una buena parte de su obra, Del Río no se refiere directamente a objetos y sustancias, sino a las presuntas potestades sobrenaturales concedidas a los hombres por mediación del diablo, especulando sobre si pueden ser encantados o si pueden llegar a hablar los animales. En ese punto se muestra condescendiente con la creencia generalizada de que ello es posible, asunto en el que coincidía con otros teólogos que escribieron sobre la materia. Difícil lo tendrían en esos casos los inquisidores a la hora de utilizar tales indicios como prueba procesal de pacto con el demonio, pero no hay que olvidar algunos casos recogidos en la Biblia, como el de la serpiente que tentó a Eva ${ }^{82}$. Lo mismo sucede con la posibilidad, también comúnmente admitida, de gozar del don de la ubicuidad por intercesión diabólica.
${ }^{80}$ Ibid., L. II, Qu. III.
${ }^{81}$ Ibid., Qu. IX-XI.
${ }^{82}$ Ibid. Qu. XIII-XIX. 
El libro III de las Disquisitionum está dividido en dos partes, dedicándose la primera al concepto y clases de maleficios. Se hace especial hincapié en los de tipo amoroso y en las ya mencionadas «ligaduras». También en estos adquieren protagonismo ciertos objetos materiales más que las propias ceremonias en el marco de las cuales se intentaban conseguir mágicamente efectos sentimentales relacionados con el amor o, en su caso, otros dañinos contra el prójimo ${ }^{83}$. Existían en cada territorio determinadas sustancias vegetales, animales o minerales con las cuales se elaboraban bebedizos o ungüentos que se utilizaban para los sortilegios amorosos. $\mathrm{Al}$ tratarse generalmente de elementos extraídos de la naturaleza circundante, variaban enormemente de unas regiones a otras. Ese seguramente es el motivo por el cual rara vez los tratadistas se aventuraban a especificar tales objetos.

En cuanto a las ligaduras (Maleficium ligaminis), también interviene en ellas el elemento material que fue hallado innúmeras veces a lo largo y ancho del continente europeo entre las ropas o pertenencias de los hechiceros. Se trataba de cuerdas o cordones anudados de manera que simbolizaran la incapacidad de los maleficiados para el coito o para generar prole, amén de otros maleficios. Supuestamente, el efecto dañino desaparecería cuando el sortílego desatara los nudos ${ }^{84}$.

En su afán de exhaustividad, también alude Del Río a las diferentes ceremonias, oraciones y otras manifestaciones indiciarias del sortilegio herético. En ciertos casos no se pone de manifiesto por el hallazgo de objetos específicos, sino que más bien se requiere otro tipo de prueba para demostrar procedimentalmente su existencia, como puede ser la testifical. Sin embargo, era frecuente que la realización de tales rituales llevara aparejados elementos de tipo material, por ejemplo, el hecho de recogerse ciertas hierbas en determinados días del año, sumergir imágenes sacras en el agua, usar ciertos libros y partes de animales que se echaban a fuego, etc.

Las botellas también se utilizaban frecuentemente en los conjuros, al igual que la paja, el aceite, los clavos, ciertos animales y, por supuesto, la efusión de la propia sangre. Todos esos elementos juntamente con otros que también se mencionan, como las hierbas, los anillos y los cabellos, pueden hallarse en los expedientes procesales por ese tipo de delitos a lo largo y ancho de todo el universo cristiano ${ }^{85}$.

${ }^{83} \mathrm{Ibid}$., Libro III, Qu. IV. El autor trata de los venenos y filtros de manera genérica, sin especificar sustancias concretas.

${ }^{84}$ Ibid., IV, VIII.

${ }^{85}$ Ibid., VI y VIII. 
El tratamiento de los filtros que se suministraban en diferentes sortilegios se halla diseminado a lo largo de la obra del jesuita. Se alude a los amatorios $^{86}$ y a los curativos ${ }^{87}$.

También se mencionan de manera especial ciertos sellos, anillos, imágenes y caracteres para determinar su posible fuerza mágica. Los anillos son una constante en la historia de las prácticas supersticiosas ${ }^{88}$.

Este autor niega rotundamente el valor mágico de los amuletos y colgantes cuando estos no reproducen símbolos relativos a la ortodoxia religiosa. No se admite, pues, la plasmación de figuras paganas encaminada a la obtención de efectos sobrenaturales ${ }^{89}$.

Otros muchos objetos aparecen reseñados como sospechosos de magia diabólica a lo largo de los seis libros que componen la obra de Del Río. La inmensa mayoría de ellos coinciden con aquellos que se hallaban siempre presentes en las mentes de los inquisidores y otros jueces que perseguían los delitos de brujería. Aunque no se sistematiza ese elenco, podemos citar aquí las sustancias líquidas utilizadas para administrar los sacramentos, tales como el agua bendita ${ }^{90}$ y óleos ${ }^{11}$ utilizados en el bautismo o la extremaunción, así como el plomo licuado ${ }^{92}$.

También se citan ciertas partes del cuerpo humano, como los huesos y los cabellos ${ }^{93}$, que son de uso muy frecuente en las prácticas sortílegas, recordando el autor que las brujas no dudan en profanar los sepulcros para conseguirlos $^{94}$.

Esas páginas mencionan además la utilización de algunos animales, especialmente las aves ${ }^{95}$, a la hora de practicar augurios, en consonancia con tradiciones antiquísimas documentadas ya en la Antigüedad clásica. También se citan las plantas, comúnmente usadas en las ceremonias adivinatorias o para elaborar filtros ${ }^{96}$.

${ }^{86}$ Ibid., II, III.

${ }^{87}$ Ibid., III, II C.

${ }^{88}$ Ibid., I, Cap. IV, Qu.I: «An vis Characterum, annulorum, sigilorum aut imaginum sit, qualem magi contendunt»

${ }_{89}$ Ibid., I, Qu. IV: «De amuletis et periaptis: amuleta buiusmodi quae collo dependent vim nullam obtinet naturalem ratione verborum, characterum vel figurae, vel constellationis».

${ }^{90}$ Ibid., VI, II, D y I, E.

${ }^{91}$ Ibid., I, III, C y I, IV, C.

${ }_{92}$ Ibid., III, III.

${ }_{93}$ Ibid., V, II, C y III, 2, C.

${ }^{94}$ Ibid., I, III, C.

${ }^{95}$ Ibid., IV, E, II También se citan los huevos de las propias aves (I. III, A).

${ }^{96}$ Ibid., V, III, E, II. 
Se les atribuían poderes mágicos a ciertos productos minerales de gran valor, como es el caso del coral ${ }^{97}$. Ese elenco incluye también algunos alimentos muy frecuentes en los conjuros, tales como el pan y la sal ${ }^{98}$. No se olvida el autor de incluir otras prácticas sortílegas frecuentes en toda Europa donde intervenían las espadas ${ }^{99}$.

Además, en su intento de resultar exhaustivo, Del Río menciona de manera específica los propios ungüentos utilizados por las brujas sobre sus propios cuerpos, sin aludir de forma concreta a las sustancias que utilizaban en su elaboración, probablemente por el motivo ya mencionado de variar los ingredientes dependiendo de los distintos territorios y las plantas a las cuales los hechiceros tuvieran acceso dentro de los mismos ${ }^{100}$.

En ocasiones, no inducen tanto a sospechar de la existencia del crimen ciertos objetos concretos como el símbolo en ellos contenido o representado con el fin de conseguir efectos sobrenaturales. Ese es, por ejemplo, el caso del signo de la cruz, que nos encontramos como indicio de vana observancia o de supersticiones heréticas en multitud de expedientes judiciales sustanciados contra los presuntos brujos y sortílegos. Hay casos en que se dibujaba la cruz en el suelo o se formaba con dos maderas cruzadas e incluso simplemente utilizando dos clavos. Por ello la doctrina, como en el caso concreto de Del Río, aludía al símbolo más que a los propios materiales que lo formaban ${ }^{101}$.

Los grandes ausentes en su obra son los espejos, generalmente mencionados por muchos tratados que incluyen un elenco de objetos con implicaciones demoniacas y que estaban especialmente en el punto de mira de las autoridades eclesiásticas ${ }^{102}$.

Otro autor que debe ser mencionado debido a la trascendencia de su obra en todo lo referente a la represión de las diferentes herejías es el italiano César Carena, autor de un tratado que mereció la atención y el respeto de todos los tribunales inquisitoriales ${ }^{103}$. Su Tracta-

${ }^{97}$ Ibid., VI, D, II

98 Ibid., I, I.

99 Ibid., I, A, II.

100 Ibid., I, III, D.

${ }^{101}$ Ibid., III, VIII, E y VI, A, II.

102 Bula pontificia promulgada por Juan XXII en 1326 titulada Super Illius Specula, en alusión, precisamente, al frecuente uso de espejos en las prácticas sortílegas.

${ }^{103}$ César Carena nació en Cremona (1597) y falleció en Milán (1659). Estudió teología en la universidad de Padua y Derecho en la de Pavía, donde se doctoró en 1619. El obispo de Cremona Pietro Campori lo nombró auditor en 1625. Desde 1626 fue consultor y desde 1627 fiscal del Tribunal de la Inquisición de Cremona. En 1649 se trasladó a Milán, donde falleció en 1659. Este autor debe su fama al Tractatus de modo proceden- 
tus $^{104}$ no se limita al crimen que nos ocupa con ser el que tiene mayor peso específico a lo largo de sus páginas, sino que se constituye en una obra generalista sobre la forma en que han de proceder los inquisidores ante cualquier manifestación herética. En su obra, dividida en tres partes, dedica un título completo de la segunda a los sortilegios. Arremete este autor primeramente contra el sistema utilizado hasta entonces en muchos tribunales europeos donde ante cualquier acusación por hechicería se procedía a encarcelar y torturar inmediatamente a los reos, sin tener suficientes indicios del delito. A lo largo de esas páginas van apareciendo objetos que él considera ser indicios con «olor de herejía», a fin de que los jueces puedan incluirlos entre las pruebas del delito. A pesar de ser un título extenso, no es exhaustivo y no incluye solamente pruebas materiales, sino que también alude a ceremonias y rituales sospecho$\operatorname{sos}^{105}$. Al final deja abierto el elenco de posibles elementos probatorios de cargo contra los reos remitiéndose a otros autores que habían escrito sobre el particular ${ }^{106}$.

Esa obra gozó de gran predicamento entre los tribunales inquisitoriales cuando se dedicaban a juzgar los delitos de brujería y supersticiones. Aunque su Tractatus data de 1636, la versión más conocida data de 1641. El autor dedica el libro III y último de su obra al crimen de brujería.

Resulta muy clarificadora la introducción que redacta Carena antes de proceder a ofrecer las directrices para una correcta instrucción del proceso por brujería y supersticiones. De entrada, hace notar las numerosas ocasiones en que han sido condenadas muchas mujeres por el delito de brujería, aludiendo concretamente a los procesos ante el tribunal de Logroño por el brote de Zugarramurdi, donde las presuntas brujas fueron juzgadas y casti-

di in causis Sancti Officii, publicado en 1636. A partir de la segunda edición, fechada en 1641, esta obra fue titulada Tractatus de officio Sanctissimae Inquisitionis et modo procedendi in causis fidei.

${ }_{104}$ Tractatus de Officio Sanctissimae Inquisitionis, et modo procedendi in causis fidei. Utilizamos la edición de Cremona fechada en 1655, fijándonos especialmente en su tercera parte titulada $A d$ modum procedendi in causis strigum E maleficorum. (L. III, pp. 536-552), disponible en https://books.google.es/books? id=DM5g8QTnSf0CEprintsec=frontcoverEdq $=$ Tractatus + de + officio + sanctissimae + inquisitionis $\varepsilon h l=e s \varepsilon s a=X \varepsilon v e d=2 a b U K E w i o 1 K T 36$ $X t A b U R E B Q K H b 09 D s o Q 6 A E w A H o E C A Q Q A g \# v=$ onepage $\varepsilon q=$ strigibus $E f=$ false (consultado el 5 de febrero de 2021).

${ }^{105}$ Ibid. En la parte II, Tít. XII, De sortilegis, pp. 191-233, se fija el autor en los posibles indicios de criminalidad, concretamente en las pp. 216-217. Después de citar algunos de esos indicios utiliza expresiones tales como «alia similia instrumenta», dejando así abierto el elenco de posibles pruebas del delito.

${ }^{106}$ Ibid., p. 219: «De nonnullis aliis inditiis in hoc crimine: plura alia inditia in hoc crimine a Doctoribus nostris enumerantur, quae utile erit in praesentiarum recensere». 
gadas sin las debidas cautelas procesales y basándose los jueces en indicios que Carena considera demasiado leves para proceder a tan graves condenas. Los presuntos infanticidios cometidos por aquellas que fueron acusadas de los mismos, según este autor, no aparecen suficientemente probados y él los considera bastante improbables. De ese modo nos va aproximando en su introducción a los que deben considerarse verdaderos indicios racionales de esa modalidad herética, rechazando la confesión obtenida por medio de torturas crueles. Enlaza directamente en sus planteamientos, a nuestro modo de ver, con aquellos que fueron plasmados por el inquisidor Salazar y Frías en su conocido y esclarecedor informe redactado en 1612, donde se declaraba ser ilusión de los pretendidos brujos el conjunto de fenómenos supuestamente mágicos y de crímenes que habían confesado durante los procesos que tuvieron lugar tras los sucesos de Zugarramurdi. Para evitar en el futuro semejantes errores judiciales, Carena propone unas reglas que deben ser tenidas en cuenta cuando se trata de abordar ese tipo de crímenes.

A continuación, se centra este autor en el maleficio consistente en causar enfermedades, motivo muy frecuente de acusación por el delito de brujería, advirtiendo la necesidad de convocar a los médicos para que visitaran al presuntamente maleficiado a fin de que emitieran un dictamen sobre las posibles causas naturales de la dolencia que se achacaba a maleficios ${ }^{107}$. Se trata de una muestra más del racionalismo que, según Carena, debía impregnar todo el procedimiento por el crimen en cuestión.

En cuanto a los objetos que deben investigarse para apreciar la existencia de los delitos de brujería y supersticiones, este autor se refiere concretamente a los indicios materiales en la parte tercera de su obra, dentro del apartado dedicado al registro del domicilio de los reos que debe ser sistemáticamente ordenado por los inquisidores antes de proceder a encarcelar a las brujas y continuar con el proceso. En este punto cabe resaltar que Carena siempre se refiere a estos delincuentes en su versión femenina. Alude siempre a las «brujas».

A lo largo de esas páginas, este autor entra de lleno en los indicios que deben ser observados por los inquisidores a la hora de determinar la existencia y gravedad de estos delitos. En primer lugar, propone unas instrucciones para examinar correctamente el cuerpo del delito. Una vez más, Carena no puede ni quiere ser exhaustivo en la enumeración de estos indicios, sino que cita un ejemplo clarísimo, cual es el del cuerpo sin vida de la criatura presuntamente asesinada por medio de hechizos. Cita además la

${ }^{107}$ Ibid., Parte III, De Strigibus, pp. 539-540: «Secundus. De iuditio medicorum». 
necesidad de examinar los testimonios de sus parientes antes de proceder al prendimiento de los acusados ${ }^{108}$.

Debía ordenarse también el registro de la vivienda de los presuntos maléficos y de las pretendidas víctimas en busca de otros indicios materiales que pudieran aportar pistas acerca de las actividades heréticas llevadas a cabo por los mismos ${ }^{109}$. El autor se sirve de ese apartado concreto para determinar muchos de los objetos indicativos de posibles tratos con el demonio. Son los tradicionales, ya recogidos en otros tratados anteriores. Una vez más, no pretende Carena ser exhaustivo en su enumeración, pero su listado ofrece un repertorio bastante completo que servía de guía a los notarios y familiares de la Inquisición que llevaban a cabo los mencionados registros domiciliarios ${ }^{110}$. Tampoco reseña los espejos a lo largo de esa nómina de artículos esotéricos.

\section{A MODO DE RECAPITULACIÓN}

Los autores reseñados proporcionaban suficiente fundamento doctrinal a los tribunales del Santo Oficio a la hora de juzgar los crímenes relacionados con el mundo del ocultismo, compensando así la escasez de normas propiamente inquisitoriales. El delito de brujería y supersticiones era uno de esos llamados «delitos ocultos», que se practicaban preferentemente de forma secreta e íntima. Por eso, a la hora de instruir proceso por esos crímenes, la carencia de testigos determinaba que las pruebas materiales jugaran un papel fundamental en el momento de decidir la culpabilidad o la inocencia de los reos.

Lo más destacable cuando se considera cualquier repertorio doctrinal de objetos presuntamente mágicos consiste en la cotidianidad de la mayoría de ellos. Ya se ha aludido a ese curioso fenómeno de retroalimenta-

${ }^{108}$ Ibid., p. 538: «Primus: De probando corpore delicti in hoc crimine».

109 Ibid., pp. 540-541: «Tertius. De indiciis contra maléficos perscrutandis».

110 Ibid., pp. 541-543: «Quartus. De pesquisitione domus maleficiati». Los oficiales y ministros inquisitoriales diputados por los tribunales para llevar a cabo esos registros domiciliarios debían informar al tribunal cuando encontraran en las dependencias examinadas los siguientes artículos: imágenes de cera con alfileres y otros objetos punzantes atravesados en las mismas, polvos, ungüentos, pentáculos, cartas (escritos) con cruces, libros que contengan maleficios, ollas sepultadas, venenos, huesos de difunto, todos los objetos extraordinarios y las cosas halladas en los lechos de la casa, otros objetos relacionados con todo lo anterior, documentos con círculos y cruces además de signos mágicos... Los objetos supuestamente relacionados con el demonio encontrados en las camas, así como otros como agujas, clavos, etc., deben considerarse menos importantes que los anteriormente reseñados. 
ción e interacción involuntaria entre quienes redactaban los tratados escritos para reprimir tales crímenes y los propios sortílegos. Los prácticos de la magia heterodoxa conocían en ocasiones a través de esos libros doctrinales cuáles eran los objetos y sustancias que, según sus creencias, podrían ayudarles a conseguir los efectos mágicos que pretendían alcanzar. Por otro lado, la doctrina jurídica que versaba sobre esos delitos indagaba en el ámbito popular sobre los artículos utilizados por los hechiceros para llevar a cabo sus conjuros y ceremonias, plasmándolos en sus obras con el fin de que los inquisidores supieran localizar pruebas fehacientes de las actividades heréticas que se les achacaban a los reos.

A modo de conclusión, podríamos clasificar en varios tipos los indicios materiales de criminalidad relativos a los delitos de supersticiones y brujería. En primer lugar, cabe mencionar los objetos equívocos. Eran aquellos que, so color de tener forma y consistencia de artículos destinados a las prácticas religiosas ortodoxas, entremezclaban elementos sospechosos de herejía. Hemos mencionado las cruces de diferentes materiales cuando, por ejemplo, se colocaban con los brazos invertidos. También había escritos con oraciones a ciertos santos que habían sido grandes pecadores en vida, ampliamente utilizados en ceremoniales supersticiosos, como es el caso de las oraciones a santa Elena, por citar un ejemplo. En estos casos los inquisidores tenían que indagar sobre las verdaderas intenciones de quienes poseían esos objetos a fin de determinar si se utilizaban de manera verdaderamente piadosa y ortodoxa o si se hallaba entremezclado el elemento demoniaco y la vana observancia.

En otras ocasiones los objetos y sustancias se extraían de la propia naturaleza y consistían, por ejemplo, en minerales tales como la magnetita o en plantas entre las que se encontraban, por ejemplo, el romero o la ruda. También el plomo, el oro, la plata, el azufre y un sinfín de metales además de otros elementos afines gozaban de poderes mágicos según la creencia popular. Lógicamente, en esos casos el elenco variaba según las diferentes zonas geográficas y los inquisidores tenían que aplicarse en el conocimiento de los que se utilizaban en las áreas donde ejercían su jurisdicción los tribunales del Santo Oficio. Ahí no resultaban de gran ayuda las obras doctrinales al uso, puesto que sus autores, como ya se ha señalado, habían evitado deliberadamente ser exhaustivos a la hora de elaborar la lista de todos esos indicios, recurriendo, según se ha visto, a expresiones tales como «y otros similares». Los animales, particularmente los de color negro, también se usaban en multitud de conjuros. En bastantes ocasiones se trataba de aves de corral, aunque también otras especies 
salvajes eran utilizadas en esas ceremonias, como es el caso de los búhos, cuervos, etc. En el norte de la península ibérica y en otros territorios de la Europa húmeda los sapos gozaban de gran predicamento como animales mágicos. Los gatos ocupaban el primer lugar entre los mamíferos. Todavía la estampa del gato negro tiene connotaciones mágicas.

También se recurría en los conjuros supersticiosos a objetos consagrados. Estos tenían, a la vista de los inquisidores, un elevado «olor a herejía». Nos referimos a partes extraídas de edificios o lugares consagrados, tales como iglesias o cementerios. A veces los sortílegos se hacían con un trozo de piedra arrancada de un altar o con huesos de difunto, cálices, los santos óleos y un largo etcétera, donde se incluyen objetos tan macabros como la soga de los ahorcados. Incluso existían prácticas tales como extraer de la boca la hostia después de comulgar para utilizarla en determinados conjuros. Todavía sigue existiendo un mercado importante para estos artículos.

Por último, cabe reseñar manufacturas que se utilizaban en la vida cotidiana y que, convenientemente «preparados» o «adobados» por medio de conjuros, ceremonias y rituales, se transformaban en objetos mágicos. Podemos incluir en este grupo las velas, figuras de cera, clavos, monedas, alfileres, naipes, cordeles, cuencos, anillos, espadas, cedazos, tijeras, espejos, etc. La lista es infinita. Tampoco la doctrina ha intentado hacer elencos exhaustivos de los mismos. Sin embargo, cabe destacar que su uso para tales fines es antiquísimo y se hallaba extendido por todo el universo cristiano, tanto en Europa como en los territorios de ultramar, ya fueran católicos o protestantes. Los inquisidores y sus dependientes tenían que conocer el mayor número posible de estos indicios para utilizarlos como pruebas materiales a lo largo de los procesos por brujería y supersticiones.

A pesar del racionalismo imperante en la civilización occidental desde el siglo XVIII en adelante y de la desaparición de los mencionados crímenes de herejía como tales dentro del panorama del Derecho penal, lo cierto es que las prácticas mágicas han sobrevivido a las transformaciones jurídicas de tal modo que esos objetos y sustancias, que en su día fueron indicios de delito, siguen utilizándose ampliamente durante nuestros días para la realización de sortilegios, pudiendo hallarse la mayoría de ellos en cualquier comercio de artículos esotéricos o tienda de santería. 


\section{BIBLIOGRAFÍA}

BARRERA, D.: La Cruzada albigense y el imperio aragonés: la verdadera historia de los cátaros, Madrid, Nowtilus, 2007.

Bellomo, M.: La Europa del Derecho común, Roma, Il Cigno Galileo Galilei, 1996.

Bodin, J.: De la Demonologie des Sorciers, París, Jacques du Puys, 1587.

Bolaños Mejías, C.: «La literatura jurídica como fuente del derecho inquisitorial», Revista de la Inquisición, núm. 9 (2000), pp. 191-220.

Carena, C.: Tractatus de modo procedendi in causis Sancti Officii, publicado en 1636. A partir de la segunda edición, fechada en 1641, esta obra fue titulada Tractatus de officio Sanctissimae Inquisitionis et modo procedendi in causis fidei (en este estudio utilizamos la edición de Cremona, 1655).

Castañega, M.: Tratado de las supersticiones, bechicerías y varios conjuros y abusiones, y de la posibilidad y remedio dellas, Logroño, Miguel de Eguia, 1529.

Ciruelo, P.: Tratado en el qual se reprueban todas las Supersticiones y Hechizerias: muy útil y necessario a todos los buenos Christianos zelosos de su salvación, Alcalá de Henares, 1538 (en este estudio utilizamos la edición de Barcelona, Sebastian de Cormellas, 1628).

De Castro, A.: Adversus omnes haereses, París, Jod. Badius, 1534.

- De iusta haereticorum punitione, Salamanca, Juan de Junta, 1547.

Del Río, M.: Disquisitionum magicarum libri sex, Lovaina, 1599 (en este estudio utilizamos la edición de Venecia, Iacobum Sarzinam, 1640).

- Disquisitionum Magicarum Libri sex, Maguncia, Albin, 1612.

Eymeric, N.: Manual de Inquisidores para uso de las Inquisiciones de España y Portugal, ó compendio de la obra titulada Directorio de Inquisidores, de Nicolao Eymerico, Inquisidor general de Aragón, traducida del francés al castellano por D. J. Marchena, Montpellier, Imprenta de Feliz Aviñon, 1821.

Eymeric, N., y PeÑA, F.: Directorium Inquisitorum, Venecia, 1595.

ForTeA, J. A. (ed.), Manual de Inquisidores. Directorium Inquisitorum de Fray Nicolás Eymeric, traducción y prólogo, Madrid, La Esfera de los Libros, 2006.

Grilland, P.: Tractatus de Hereticis et sortilegiis omnifariam coitu: eorumque penis, Lyon, 1536.

Henningsen, G.: El abogado de las brujas. Brujería vasca e Inquisición española, Madrid, Alianza Editorial, 1983.

Kramer, H., y Sprenger, J.: Malleus Maleficarum, Lyon, 1669.

MADRID, R.: «El delito de brujería en el libro segundo de las Disquisitionum Magicarum de Martín del Río», Teología y Vida, vol. 56, núm. 4 (2015), pp. 351-377.

O’SHEA, S.: Los cátaros: la herejía perfecta, Barcelona, Zeta Bolsillo, 2010 (1. a ed., 2002).

Pérez Martín, A.: El Derecho procesal del Ius Commune, Murcia, Universidad de Murcia, 1999.

Foro, Nueva época, vol. 23, núm. 2 (2020): 99-147 
Pradilla, F. de la: Summa de las leyes penales, Madrid, Imprenta del Reyno, 1639.

Torreblanca VillalPando, F.: Epitome Delictorum sive de Magia in qua aperta vel occulta invocatio daemonis intervenit, Sevilla, Ildephonsum Rodriguez Gamarra \& Franciscum de Lira, 1618 (en este estudio utilizamos la edición de Lyon, Jean Anton Hugetan, 1678).

Simancas, D.: De Catholicis Institutionibus Liber ad Praecavendas E Extirpandas haereses admodum necessarius, 1554 (en este estudio utilizamos la edición complutense de Andream de Angulo, 1569).

\section{Webgrafía}

Bodin, J.: De la Demonologie des Sorciers, París, 1587, disponible en https://babel. bathitrust.org/cgi/pt? id=dul1.ark:/13960/t6155j30bEview=1upEseq=5 (consultado el 12 de octubre de 2020).

Carena, C.: Tractatus de modo procedendi in causis Sancti Officii, publicado en 1636. A partir de la segunda edición, fechada en 1641, esta obra fue titulada Tractatus de officio Sanctissimae Inquisitionis et modo procedendi in causis fidei (en este estudio utilizamos la edición de Cremona, 1655), disponible en bttps://books.google.es/books? id=DM5g8QTnSf0CEprintsec=frontcoverEdq= Tractatus +de+officio +sanctissimae + inquisitionis $\varepsilon h l=e s \varepsilon s a=X \varepsilon v e d=2 a b U K E$ wio1KT36_XtAbUREBQKHb09DsoQ6AEwAHoECAQQAg\#v=onepageEq= strigibus $E f=$ false (consultado el 5 de febrero de 2021).

Castañega, M.: Tratado de las Supersticiones, bechicerías y varios conjuros $y$ abusiones, $y$ de la posibilidad y remedio dellas, Logroño, 1529, disponible en https://www.researchgate.net/publication/266078458_Fray_ Martin_de_Castanega_Tratado_de_las_Supersticiones_y_Hechizerias/linkl 5534fedc0cf2ea51c13376bf/download (consultado el 8 de enero de 2021).

Ciruelo, P.: Tratado en el qual se reprueban todas las Supersticiones y Hechizerías: muy útil y necessario a todos los buenos Christianos zelosos de su salvación, Alcalá de Henares, 1538 (en este estudio utilizamos la edición de Barcelona, 1628), disponible en http://www.cervantesvirtual.com/obras/autor/ciruelopedro-18096 (consultado el 15 de enero de 2021).

De Castro, A.: Adversus omnes haereses, París, 1534, disponible en bttps://babel. bathitrust.org $/ \mathrm{cgi} /$ pt?id=ucm.5319430647Eview $=1$ up $\varepsilon$ seq $=8$ (consultado el 8 de noviembre de 2020).

- De iusta haereticorum punitione, Salamanca, 1547, disponible en https://babel. bathitrust.org $/ \mathrm{cgi} /$ pt? id=ucm.5325043668\&view=1up\&seq=5 (consultado el 8 de noviembre de 2020).

Del Río, M.: Disquisitionum magicarum libri sex, Lovaina, 1599 (en este estudio utilizamos la edición de Venecia, 1640), disponible en bttps://books.google.es/books/ about/Disquisitionum_magicarum_libri_sex.html?id=VEDIwQEACAAJEredir_ esc $=y$ (consultado el 1 de febrero de 2021). 
Eymeric, N.: Manual de Inquisidores para uso de las Inquisiciones de España y Portugal, ó compendio de la obra titulada Directorio de Inquisidores, de Nicolao Eymerico, Inquisidor general de Aragón, traducida del francés al castellano por D. J. Marchena, Montpellier, 1821, disponible en http://www.bibliothecasefarad.com/listado-de-libros/manual-de-inqui sidores-para-uso-de-las-inquisiciones-de-espana-y-portugal-o-compendio-de-la-obra -titulada-directorio-de-inquisidores-de-nicolao-eymerico-inquisidor-general-dearagon/ (consultado el 3 de diciembre de 2020).

Eymeric, N., y PeÑA, F.: Directorium Inquisitorum, Venecia, 1595, disponible en bttps://books.google.es/books/ucm?vid=UCM5316847848Eprintsec=frontcove $r E$ redir_esc $=y \# v=$ onepageE $q \mathcal{E} f=$ false (consultado el 14 de diciembre de 2020).

Grilland, P.: Tractatus de Hereticis et sortilegiis omnifariam coitu: eorumque penis», Lyon, 1536, disponible en https://babel.hathitrust.org/cgi/pt?id=ucm.5 317952473Eview=1up\&seq=1 (consultado el 20 de diciembre de 2020).

Kramer, H., y Sprenger, J.: Malleus Maleficarum, Lyon, 1669, disponible en bttps://books. google.es/books/ucm?vid=UCM5319051264Eprintsec=frontcove rEredir_esc $=y \# v=$ onepage $\varepsilon q \varepsilon f=$ false (consultado el 8 de septiembre de 2020).

MADRID, R.: «El delito de brujería en el libro segundo de las Disquisitionum Magicarum de Martín del Río», Teología y Vida, vol. 56, núm. 4 (2015), pp. 351-377, disponible en https://www.researchgate.net/publication/293799661_El_delito_de_brujeria_en_el_Libro_Segundo_de_las_Disquisitionum_Magicarum_de_ Martin_del_Rio (consultado el 25 de enero de 2021).

Pradilla, F. de la: Summa de las leyes penales, Madrid, 1639, disponible en https:// babel.hathitrust.org/cgi/pt?id=ucm.5319430647Eview $=1$ up $\varepsilon s e q=8$ (consultado el 22 de octubre de 2020).

Simancas, D.: De Catholicis Institutionibus Liber ad Praecavendas E Extirpandas haereses admodum necessarius, 1554 (en este estudio utilizamos la edición complutense de 1569), disponible en bttps://babel.hatbitrust.org/cgi/pt?id=ucm.53 16850711Eview $=1$ up Eseq=5 (consultado el 20 de enero de 2021).

Torreblanca VillalPando, F.: Epitome Delictorum sive de Magia in qua aperta vel occulta invocatio daemonis intervenit, Sevilla, 1618 ((en este estudio utilizamos la edición de Lyon, 1678), disponible en https://babel.hathitrust.org/cgi/pt?id= ucm.5317963888Eview=1up\&seq=7 (consultado el 7 de enero de 2021). 